\title{
Kilka uwag o sposobach rozstrzygania sporów dotyczących sprawczego współdziałania w popełnieniu przestępstwa indywidualnego
}

\author{
PiOTR KARDAS \\ Katedra Prawa Karnego \\ Uniwersytet Jagielloński
}

Profesor Tomasz Kaczmarek to szczególna postać w polskiej nauce prawa karnego. Mimo upływającego nieubłaganie czasu zachowuje nadzwyczajną ostrość spojrzenia i charakterystyczną dla jego twórczości naukowej kreatywność. Teksty Profesora Tomasza Kaczmarka czyta się zawsze nie tylko z wielką przyjemnością, z uwagi na nadzwyczajną elegancję słowa, lecz przede wszystkim z tego powodu, że zawierają spojrzenie właściwe dyskursowi naukowemu, albowiem Profesor jest przede wszystkim uczonym zachowującym właściwy uczonemu dystans do otaczającej rzeczywistości i odporność na uleganie modom i dążeniom do uzyskania funkcji lub publicznych zaszczytów, oddającym się w zaciszu domowego gabinetu, pełnego ksiąg wszelakich, poszukiwaniom odpowiedzi na pytania dla karnistyki fundamentalne. Co rusz zaskakuje nowatorstwem podejścia, prezentując poglądy dotyczące podstawowych zagadnień współczesnego prawa karnego, nigdy jednak nie traci właściwej relacji z tradycją, zachowując to, co w karnistyce stanowi nienaruszalny fundament, bez którego wszelkie dywagacje tracą naukowy sens, stając się czystą spekulacją. Od lat mam zaszczyt zaliczać się nie tylko do szeroko rozumianego grona uczniów Profesora Tomasza Kaczmarka, lecz także kręgu Jego bliskich przyjaciół. Nie sposób zliczyć rozmów, które w różnej formie, mimo dzielącej nas na co dzień między Wrocławiem a Krakowem odległości, przeprowadziliśmy w trakcie ostatnich dwudziestu lat. Nie sposób spłacić długów intelektualnych, które zaciągnąłem, poszukując u Profesora wsparcia i oceny podejmowanych przeze mnie prób odniesienia się do wielu zagadnień dogmatycznych. Możliwość zamieszczenia tekstu w księdze jubileuszowej związanej z 80. rocznicą urodzin Profesora traktuję zatem jako wyzwanie nadzwyczajne. By uhonorować uczonego tej miary, nie chodzi przecież tylko o skreślenie kilku uwag dotyczą- 
cych jednego z obszarów, którymi Profesor przez lata się zajmował, lecz o to, by próbując dorównać Mistrzowi, zawrzeć w dedykowanym Mu opracowaniu myśli niebanalne.

Poszukując tematu, którego analizę chciałem dedykować Profesorowi Tomaszowi Kaczmarkowi wśród wielu zagadnień stanowiących przedmiot rozważań w jego pracach, wybrałem temat, który w pewnym zakresie stanowił przedmiot toczonych między nami sporów, tj. kwestię podstaw odpowiedzialności ekstraneusa za sprawcze współdziałanie w popełnieniu przestępstwa indywidualnego ${ }^{1}$. Zagadnienie to jest częścią złożonej problematyki podstaw odpowiedzialności za współdziałanie w przypadku przestępstw o indywidualnej charakterystyce podmiotu sprawczego ${ }^{2}$. Obszar ten od lat stanowi jeden z najbardziej spornych i zarazem $\mathrm{w}$ niewielkim stopniu wyjaśnionych problemów w teorii i dogmatyce prawa karnego. Bez ryzyka popełnienia większego błędu można stwierdzić, że jednym z zasadniczych powodów sporności tej części analiz dotyczących podstaw odpowiedzialności karnej jest to, że w tym zakresie nakładają się na siebie dwie wyjątkowo złożone kwestie - teoretycznych podstaw i dogmatycznej rekonstrukcji przesłanek i zakresu odpowiedzialności za przestępne współdziałanie ${ }^{3}$ oraz zagadnienie teoretycznego objaśnienia i dogmatycznego uporządkowania tzw. przestępstw indywidualnych ${ }^{4}$. Zapewne też $\mathrm{z}$ tych względów tytułowe zagadnienie bywa analizowane szczątkowo w związku z badaniami nad problematyką współdziałania lub w kontekście analiz dotyczących przestępstw indywidualnych, choć można także odnaleźć w polskim piśmiennictwie prace odnoszące się do szczegól-

1 Zob. w szczególności stanowisko T. Kaczmarka, Recenzja książki Piotra Kardasa „Teoretyczne podstawy odpowiedzialności karnej za przestęne współdziałanie”, PiP 2002, nr 5, s. 102 n.; idem, Sporne problemy odpowiedzialności karnej ekstraneusa za wspótsprawstwo do przestępstw indywidualnych, [w:] Nauka wobec prawdy sadowej. Księga pamiątkowa ku czci Profesora Zdzisława Kegla, red. R. Jaworski, M. Szostak, Wrocław 2005, s. 272 n.; oraz P. Kardas Teoretyczne podstawy odpowiedzialności karnej za przestępne współdziałanie, Kraków 2001, s. 534 n.

2 Zawarte w dalszej części niniejszego opracowania rozważania w pewnym zakresie opierają się i stanowią kontynuację analiz zarysowanych pierwotnie w opracowaniu P. Kardasa, Typy zmodyfikowane ze względu na podmiot jako szczególna odmiana tzw. przestęstw indywidualnych a formy współdziałania przestępnego, [w:] Zmodyfikowane typy przestęstw $w$ teorii i praktyce prawa karnego, red. J. Giezek (w druku).

3 Zob. w tym zakresie w szczególności P. Kardas, Teoretyczne podstawy...; A. Liszewska, Współdziałanie przestęne w polskim prawie karnym. Analiza dogmatyczna, Łódź 2004; Ł. Pohl, Wyktad prawa karnego. Część ogólna, Warszawa 2012, s. 172 n.

4 Co do sposobu interpretowania pojęcia ,przestępstwo indywidualne”, przyjmowanych kryteriów podziału tych przestępstw oraz wynikających z niego konsekwencji zob. m.in. W. Bugajski, O przestępstwach indywidualnych, $\mathrm{PiP}$ 1965, nr 5-6, s. 833 n.; R. Dębski, Współdziałanie przy przestepstwie indywidualnym w ujęciu nowego kodeksu karnego, PiP 2002, nr 6, s. 22 n.; Ł. Pohl, op. cit., s. 119 n.; Ł. Pilarczyk, Istota przestepstw indywidualnych, RPEiS 76, 2014, nr 4, s. 190 n.; J. Giezek [w:] J. Giezek, N. Kłączyńska, G. Łabuda, Kodeks karny. Część ogólna. Komentarz, Warszawa 2012, s. 185-186. 
nego powiązania kwestii odpowiedzialności za przestępstwa indywidualne z problematyką współdziałania 5 .

Aktualny stan polskiej dogmatyki prawa karnego w istotnym stopniu stanowi konsekwencję przyjętego w pierwszym polskim dwudziestowiecznym kodeksie karnym modelu rozwiązywania zagadnienia podstaw odpowiedzialności za współdziałanie w popełnieniu przestępstwa, mocno zdeterminowanego poglądami twórcy tego rozwiązania - J. Makarewicza. Warto przypomnieć, że J. Makarewicz przez cały okres naukowej twórczości konsekwentnie prezentował pogląd o możliwości pociągania do odpowiedzialności karnej za przestępstwo indywidualne piśmiennictwa wyłącznie sprawcy pojedynczego ${ }^{6}$ (bezpośredniego ${ }^{7}$ ),

5 Zob. w szczególności A. Zoll, Odpowiedzialność kierującego wykonaniem przez inną osobę czynu zabronionego, NP 1970, nr 7, s. 58 n.; idem, Podżeganie i pomocnictwo do przestępstw indywidualnych w projekcie zmian przepisów kodeksu karnego, PiP 1982, nr 3-4, s. 121 n.; R. Dębski, op. cit., s. 13 n.; A. Liszewska, Odpowiedzialność za współdziałanie przy przestępstwach indywidualnych w polskim prawie karnym, CzPKiNP VIII, 2004, nr 1, s. 5 n.; T. Kaczmarek, Recenzja książki..., s. 102 n.; idem, Kwestie sporne wokót pojęcia tzw. niesprawczych form współdziałania przestępnego, [w:] Formy stadialne i postaci zjawiskowe popetnienia przestepstwa, red. J. Majewski, Toruń 2007, s. 92 n.; Ł. Pilarczyk, Postulaty nowelizacji art. 21 \& k.k. w zakresie odpowiedzialności karnej ekstraneusa za sprawstwo polecające i kierownicze oraz wspótsprawstwo przy przestepstwach indywidualnych, [w:] Reforma prawa karnego, red. I. Sepioło-Jankowska, Warszawa 2014, s. 94 n.

${ }^{6}$ Kwestię tę J. Makarewicz ujmował następująco: ,przy przestępstwach indywidualnych wykluczone jest podżeganie i pomocnictwo jako postać spełnienia czynu karalnego, choćby nawet po stronie podżegacza czy pomocnika zachodziły pełne kwalifikacje do tego, by stać się sprawcą. [...] Przestępstwo indywidualne jest indywidualne w ścisłym tego słowa znaczeniu, jest ograniczone do osoby sprawcy, posiadającego do tej roli odpowiednie kwalifikacje" — J. Makarewicz, Kodeks karny z komentarzem, wyd. piąte, Lwów 1938, s. 144.

7 Posłużenie się powyżej zwrotem „bezpośrednie” wymaga pewnego wyjaśnienia. Jakkolwiek leżąca u podstaw regulacji sprawstwa i współdziałania w popełnieniu przestępstwa koncepcja J. Makarewicza oparta była na założeniu wykluczenia w polskim systemie prawa karnego możliwości wykorzystywania znanej ustawodawstwu i doktrynie niemieckiej konstrukcji sprawstwa pośredniego, to jednak w ciągu lat, z uwagi na różnorodne czynniki, stanowczość twierdzenia o odrzuceniu przez polski system prawa karnego konstrukcji sprawstwa pośredniego znacznie złagodniała. Najpierw, ze względu na potrzeby praktyczne, nie zawsze uzasadnione z punktu widzenia dogmatycznego i kryminalnopolitycznego, jednak silnie związane z intuicyjnym poczuciem sprawiedliwości, w orzecznictwie Sądu Najwyższego pojawiły się wypowiedzi nawiązujące do konstrukcji pośredniej realizacji znamion poszczególnych typów czynu zabronionego. Później kreatywnie wykorzystywany model obiektywnego przypisania skutku prowadził do poszerzania zakresu odpowiedzialności karnej za przestępstwa skutkowe, gdy znamię skutku wywoływane było „bezpośrednio” przez inną osobę niż pociągany do odpowiedzialności sprawca. W konsekwencji aktualnie niezwykle trudno stanowczo twierdzić, że art. 18 § 1 in principio k.k. odnosi się do sprawstwa pojedynczego i zarazem bezpośredniego. Z pewnością przepis ten odnosi się do sprawstwa pojedynczego. Jednak czy chodzi tutaj także zawsze o sprawstwo bezpośrednie w znaczeniu, jakie temu sformułowaniu nadaje się w analizach z obszaru dogmatyki niemieckiej, to kwestia już w najwyższym stopniu wątpliwa. Co do odpowiedzialności za pośrednio wywoływany skutek zob. w szczególności P. Kardas, Glosa do wyroku SN z dnia 13 kwietnia 2006 r., (IV KK 40/06) dotycząca konstrukcji sprawstwa pojedynczego, sprawstwa pośredniego w kontekście możliwości 
wyłączając jednocześnie możliwość konstruowania podstaw odpowiedzialności za jakąkolwiek postać współdziałania w popełnieniu przestępstwa indywidualnego ${ }^{8}$. Twierdzenie o braku podstaw do pociągania do odpowiedzialności karnej za współdziałanie w popełnieniu przestępstwa indywidualnego odnosił zarówno do wypadków, gdy współdziałający miał status ekstraneusa, jak i sytuacji, gdy współdziałający miał cechy wymagane od sprawcy o zawężonym kręgu podmiotów. Radykalne stanowisko J. Makarewicza po krótkotrwałym okresie aprobaty zostało odrzucone w orzecznictwie Sądu Najwyższego w drugiej połowie lat $30 .{ }^{9}$ Choć praktyka przyjęła, w ślad za stanowiskiem Sądu Najwyższego, możliwości pociągania ekstraneusa do odpowiedzialności za podżeganie i pomocnictwo do przestępstw indywidualnych, to w doktrynie prawa karnego kwestia ta stanowiła przedmiot najpoważniejszych kontrowersji i sporów ${ }^{10}$. Co ciekawe, choć J. Maka-

realizacji znamienia wprowadzenia w błąd przewidzianego w art. $286 \S 1$ k.k. „za pośrednictwem innej osoby”) - „Przegląd Sądowy” 2007, nr 6, s. 150-168; J. Giezek, P. Kardas, O kryteriach obiektywnego oraz subiektywnego przypisania z punktu widzenia podstaw odpowiedzialności karnej - uwagi wprowadzające, [w:] Obiektywne oraz subiektywne przypisanie odpowiedzialności karnej, red. J. Giezek, P. Kardas, Warszawa 2016, s. 11-37; P. Kardas, W poszukiwaniu tzw. negatywnych przesłanek obiektywnego przypisania, [w:] Obiektywne oraz subiektywne..., s. 165-212. Stałe zwiększanie zakresu odpowiedzialności karnej za sprawstwo pojedyncze, w tym w szczególności odwoływanie się do różnie rozumianych konstrukcji pośredniego sprawstwa, sprawia, iż coraz częściej sprawstwo pojedyncze stanowi alternatywę uregulowanych w kodeksie karnym postaci współdziałania. Rodzi to swoiste, i co do zasady niewystępujące w czasie obowiązywania kodeksów karnych z 1932 r. i 1969 r., problemy z nakładaniem się sprawstwa pojedynczego, rozumianego szeroko jako sprawstwo pośrednie z konstrukcjami sprawczego oraz niesprawczego współdziałania. Ma także znaczenie z punktu widzenia analizowanej w tym opracowaniu problematyki współdziałania przestępnego w popełnieniu przestępstwa indywidualnego.

8 J. Makarewicz stwierdzał, że ,przy przestępstwach indywidualnych wykluczone jest podżeganie i pomocnictwo jako postać spełnienia czynu karalnego, choćby nawet po stronie podżegacza czy pomocnika zachodziły pełne kwalifikacje do tego, by stać się sprawcą" - op. cit., s. 144. Identyczne stanowisko w tej kwestii prezentowali S. Glaser, A. Mogilnicki, wskazując, że „jeżeli zatem przestępstwo jest tego rodzaju, że może je popełnić tylko osoba, mająca ustawowe po temu warunki, to, w razie popełnienia takiego przestępstwa przez dwie lub więcej osób, te osoby, które warunkom powyższym nie odpowiadają, nie będą w ogóle odpowiedzialne" - S. Glaser, A. Mogilnicki, Kodeks karny. Komentarz, Kraków 1934, s. 81-82. Zob. w tej kwestii też P. Kardas, Teoretyczne podstawy...; R. Dębski, op. cit., s. 22 n.; A. Liszewska, Odpowiedzialność..., s. 5 n. Por. też stanowisko J. Giezka — J. Giezek, N. Kłączyńska, G. Łabuda [w:] Kodeks karny. Komentarz. Część ogólna, red. J. Giezek, Warszawa 2012, s. 186-187.

9 Por. uchwałę SN z dnia 15 maja 1936 r., I K 736/36, OSP 1937, poz. 446. Zob. też w tej kwestii szerzej P. Kardas [w:] G. Bogdan et al., Kodeks karny. Część ogólna. Komentarz, Warszawa 2012, s. 402.

10 Warto zaznaczyć, że J. Makarewicz nigdy nie zmienił stanowiska co do wyłączenia wszystkich postaci współdziałania w przypadku przestępstw indywidualnych (zarówno właściwych, jak i niewłaściwych), pozostali zaś przedstawiciele środowiska karnistycznego podzielili się na dwa obozy, prowadząc interesujące spory w tym obszarze. Zob. J. Makarewicz, Bezkarność podżeganie i pomocnictwa, „Przegląd Prawa i Administracji” 1934, s. 3 n.; Z. Łubkowski, Podżeganie i pomocnictwo przy przestępstwach t. zw. indywidualnych, „Głos Sądownictwa” 1936, s. 947 n.; L. Peiper, 
rewicz kwestionował w ogóle możliwość konstruowania podstaw odpowiedzialności za współdziałanie w popełnieniu przestępstwa indywidualnego, uważając, że ta szczególna kategoria przestępstw może być realizowana wyłącznie w formie sprawstwa pojedynczego (bezpośredniego), zasadnicze spory oraz rozbieżności w orzecznictwie dotyczyły możliwości pociągania ekstraneusa do odpowiedzialności karnej za współdziałanie w popełnieniu przestępstwa indywidualnego ${ }^{11}$. Kwestia odpowiedzialności karnej intraneusa za podżeganie i pomocnictwo do przestępstwa indywidualnego nie zaprzątała w takim stopniu myśli uczonych karnistów. Jakkolwiek odpowiedzialność ta nie jest bynajmniej tak oczywista, jak mogłoby się prima facie wydawać ${ }^{12}$, to właśnie brak po stronie współdziałającego cech wymaganych od sprawcy przestępstwa o zawężonym kręgu podmiotów stanowił zagadnienie, którego rozstrzygnięcie, zdaniem wielu przedstawicieli doktryny, wymagało szczególnego ustawowego umocowania ${ }^{13}$.

Warto podkreślić, że w zakresie problematyki współdziałania ekstraneusa w popełnieniu przestępstwa indywidualnego zasadniczo chodzi o rozwiązanie kwestii możliwości pociągania do odpowiedzialności karnej osoby niemającej cech wymaganych od sprawcy przestępstwa indywidualnego, współdziałającej ze sprawcą takiego przestępstwa, $\mathrm{z}$ oczywistych powodów spełniającym określone w ustawie wymagania co do podmiotu odpowiedzialności karnej. Innymi słowy, problem współdziałania ekstraneusa w popełnieniu przestępstwa indywidualnego postrze-

Komentarz do kodeksu karnego, Kraków 1933, s. 137 n.; S. Glaser, A. Mogilnicki, op. cit., s. 81-82; S. Glaser, Polskie prawo karne w zarysie, Kraków 1933, s. 243 n.; A. Fudali, Czy przepisy art. 26-30 k.k. mają zastosowanie do delicta propria, „Przegląd Sądowy” 1993, nr 3, s. 27 n.; S. Lisocki, Karalność podżegania i pomocnictwa do przestepstw indywidualnych w kodeksie karnym polskim, Warszawa 1934, s. 83 n. Interesujące uwagi rekonstrukcyjne dotyczące tego sporu przedstawia w opublikowane w drugiej połowie lat 70. ubiegłego wieku A. Wąsek, Współsprawstwo w polskim prawie karnym, Warszawa 1977, s. $45 \mathrm{n}$.

11 Zaskakująco nie stanowiła przedmiotu rozważań problematyka odpowiedzialności intraneusa za podżeganie i pomocnictwo do przestępstwa indywidualnego, choć pierwotne i wyznaczające z znacznym stopniu zakres kontrowersji stanowisko J. Makarewicza odnosiło się także do wyłączenia możliwości odpowiedzialności intraneusa za podżeganie i pomocnictwo do przestępstwa indywidualnego.

12 Zob. szerzej w tej kwestii P. Kardas, Typy zmodyfikowane... (w druku).

13 Kwestia ta stanowi przedmiot sporów i rozbieżności stanowisk na gruncie regulacji zawartej w art. 21 § 2 k.k. z 1997 r. w przypadkach sprawstwa kierowniczego oraz sprawstwa polecającego wówczas, gdy kierujący lub wydający polecenie ma cechy wymagane od sprawcy przestępstwa indywidualnego, kierowany zaś lub adresat polecenia (bezpośredni wykonawca) ma status ekstraneusa. Zob. w tej kwestii m.in. K. Buchała [w:] Komentarz do kodeksu karnego. Część ogólna, red. K. Buchała, Warszawa 1994, s. 147 n.; R. Dębski, op. cit., s. 14-15; A. Zoll [w:] K. Buchała, A. Zoll, Kodeks karny. Część ogólna. Komentarz, Kraków 1998, s. 196; Ł. Pohl, op. cit., s. 187 n. W piśmiennictwie wskazuje się, że trudno uznać za uzasadniony pogląd, wedle którego „pojęcie »współdziałający« ma charakter dwukierunkowy w tym sensie, że odnosi się zarówno do relacji sprawca pojedynczy-współdziałający, jak i relacji współdziałający-sprawca pojedynczy" P. Kardas [w:] G. Bogdan et al., op. cit., s. 407. 
gano w perspektywie zwiększenia zakresu odpowiedzialności za przestępstwa indywidualne w przypadkach współdziałania ekstraneusa ze sprawcą (bezpośrednim wykonawcą) będącym intraneusem. W konsekwencji kwestia odpowiedzialności ekstraneusa za współdziałanie w popełnieniu przestępstwa indywidualnego aktualizuje się w tych wypadkach, gdy bezpośredni wykonawca ma wymagane ustawą cechy, współdziałający zaś z nim ma status ekstraneusa. Wydawać by się mogło zarazem, że w wypadku intraneusa nie istnieją zasadnicze przeszkody i trudności w pociąganiu do odpowiedzialności karnej za współdziałanie w popełnieniu przestępstwa indywidualnego. Tymczasem w wypadku intraneusa współdziałającego w popełnieniu przestępstwa indywidualnego występować mogą co najmniej dwa układy. Pierwszy, w którym intraneus współdziała w popełnieniu przestępstwa indywidualnego z bezpośrednim wykonawcą mającym status intraneusa. Drugi, w którym intraneus współdziała w popełnieniu przestępstwa indywidualnego z bezpośrednim wykonawcą mającym status ekstraneusa. O ile w pierwszym z wymienionych układów problematyczne może być jedynie to, co stanowiło podstawę stanowiska J. Makarewicza, a więc rozstrzygnięcie, czy przestępstwa indywidualne mogą być popełnione wyłącznie $\mathrm{w}$ formie sprawstwa pojedynczego bezpośredniego (jak twierdził J. Makarewicz), co wyklucza możliwość odpowiedzialności intraneusa za współdziałanie w popełnieniu przestępstwa indywidualnego, czy też przyjęcie, że przestępstwa indywidualne mogą być popełnione także w każdej postaci współdziałania (co przyjmowano w ślad za orzecznictwem SN, wypracowanym w drugiej połowie lat 30. ubiegłego wieku, odrzucając pogląd J. Makarewicza), co umożliwia pociągnięcie intraneusa za współdziałanie w popełnieniu przestępstwa indywidualnego, o tyle w drugim z wymienionych układów wątpliwości wywoływać może to, czy w ogóle możliwa jest jakakolwiek lub też — czy możliwe są wszystkie postaci współdziałania w popełnieniu przestępstwa indywidualnego w wypadkach, gdy bezpośredni wykonawca nie ma cech wymaganych od sprawcy przestępstwa indywidualnego, cechy takie ma natomiast współdziałający z nim intraneus. Szczególne komplikacje związane z tego typu układami ujawniają się w odniesieniu do niektórych odmian sprawczego współdziałania, tj. sprawstwa kierowniczego oraz sprawstwa polecającego, i związane są przede wszystkim z dwiema okolicznościami — twierdzeniem, że sprawstwo kierownicze i sprawstwo polecające to szczególne odmiany sprawstwa pośredniego na gruncie polskiego systemu prawa karnego, zakreślające węziej niż znana niemieckiemu prawu karnemu konstrukcja sprawstwa pośredniego zakres odpowiedzialności karnej, oraz skorelowanym z nim stanowiskiem, że obie wymienione odmiany sprawczego współdziałania stanowią — inaczej niż znane niemieckiemu systemowi prawa karnego sprawstwo pośrednie — nie tyle szczególną odmianę sprawstwa pojedynczego, ile sprawstwa pośredniego, w ramach której odpowiedzialność karną ponosić może tylko jedna osoba, choć przestępstwo popełniane jest w konfiguracji wieloosobowej (tj. co najmniej dwóch osób, sprawcy pośredniego i bezpośredniego, nieodpowiedzialnego 
wykonawcy, ludzkiego narzędzia), lecz postaci przestępnego współdziałania, stwarzające podstawę do pociągnięcia do odpowiedzialności karnej każdego ze współdziałających, zarazem jednak wymagające, by w przypadku czynności kierowania były one odniesione do zachowania stanowiącego wykonanie czynu zabronionego przez osobę kierowaną, w przypadku zaś polecenia, by jego treścią objęte było wykonanie czynu zabronionego przez adresata, co w razie posiadania przez kierowanego lub adresata polecenia statusu ekstraneusa zdaje się niemożliwe w przypadku współdziałania w popełnieniu przestępstwa indywidualnego ${ }^{14}$.

Mając na względzie kontrowersje związane z podstawami odpowiedzialności ekstraneusa za podżeganie i pomocnictwo do przestępstwa indywidualnego, nawiązując do przyjmowanego w okresie międzywojennym rozwiązania tego problemu w sposób gwarantujący właściwe funkcjonowanie systemu prawa karnego w praktyce wymiaru sprawiedliwości, do kodeksu karnego z 1969 r. wprowadzono przepis odnoszący się bezpośrednio do tej kwestii. Przyjęte w odnoszącym się do omawianego zagadnienia art. 19 § 2 k.k. z 1969 r. rozwiązanie zasadniczo opierało się na modelu wypracowanym w okresie międzywojennym, aprobowanym przez zasadniczą część doktryny i stosowanym powszechnie w orzecznictwie, także w okresie powojennym poprzedzającym wejście w życie art. 19 § 2 k.k. z 1969 r. ${ }^{15}$ Przepis art. $19 \S 2$ k.k. z 1969 r. ograniczał się jednak do problemu odpowiedzialności ekstraneusa za podżeganie i pomocnictwo do przestępstw o zawężonym kręgu podmiotów sprawczych, nie odnosił się natomiast do kwestii odpowiedzialności ekstraneusa za sprawcze współdziałanie w popełnieniu przestępstwa indywidualnego. $\mathrm{Z}$ kolei z tych względów rozwiązanie to nie mogło stanowić podstawy rozstrzygania zagadnień związanych z odpowiedzialnością karną ekstraneusa za sprawcze odmiany współdziałania ${ }^{16}$. Ten mankament starano się rozwiązać, przyjmując rozwiązanie zawarte w art. $21 \S 2$ k.k. z 1997 r., zgodnie z którym współdziałający w popełnieniu przestępstwa, którego znamiona przewidują okoliczność osobistą dotyczącą sprawcy, wpływającą chociażby na wyższą karalność, podlega odpowiedzialności za to przestępstwo, gdy o tej okoliczności wiedział, chociażby go nie dotyczyła. Wedle rozpowszechnionego stanowiska regulacja zawarta w art. 21 $\S 2$ k.k. opiera się na założeniu ujednolicenia kodeksowego ujęcia reguł odpowiedzialności osób współdziałających przy dokonaniu przestępstwa indywidualnego ${ }^{17}$.

14 Zob. szerzej w tej kwestii P. Kardas, Teoretyczne podstawy..., s. $560 \mathrm{n}$.

15 W uzasadnieniu projektu kodeksu karnego z 1969 r. wskazywano, że „przepis art. $19 \S 2$ ma zapobiec wątpliwościom i sporom, jakie wynikały na tle k.k. z 1932 r. w kwestii odpowiedzialności za podżeganie i pomocnictwo do tzw. delicta propria. Zgodnie z podstawową linią dotychczasowego orzecznictwa kodeks przyjął, że należy wyraźnie określić odpowiedzialność extraneusa za podżeganie i pomocnictwo do przestępstw indywidualnych właściwych i niewłaściwych" — s. 101.

${ }^{16}$ Zob. w tej kwestii m.in. K. Buchała [w:] Komentarz do kodeksu karnego. Czesść..., s. 147 n.; R. Dębski, op. cit., s. 14-15.

17 Trzeba jednak pamiętać, że przyjęte ostatecznie w k.k. z 1997 r. rozwiązanie było poprzedzone przedstawieniem dwóch różniących się od konstrukcji wyrażonej w art. 21 § 2 k.k. z 1997 r. 
Analizując historię kształtowania rozwiązań dotyczących przestępnego współdziałania w kolejnych polskich dwudziestowiecznych kodeksach karnych, można dostrzec, że ujawniające się $\mathrm{w}$ doktrynie i praktyce stosowania prawa trudności związane z odpowiedzialnością ekstraneusa za współdziałanie w popełnieniu przestępstwa indywidualnego stopniowo rozwiązywano, wprowadzając do kodeksów karnych regulacje szczególne ${ }^{18}$. Trzeba jednak wyraźnie zaznaczyć, że o ile przyjęty w art. 19 § 2 k.k. z 1969 r. sposób rozwiązania kwestii odpowiedzialności ekstraneusa za podżeganie i pomocnictwo do przestępstwa indywidualnego opierał się na wypracowanym w orzecznictwie stanowisku oraz daleko idącym konsensie uczonych, o tyle poszerzenie zakresu zastosowania tej regulacji na sprawcze postaci współdziałania w art. 21 § 2 k.k. z 1997 r. już takich podstaw było pozbawione, albowiem brakowało zarówno klarownej koncepcji rozstrzygania problemu sprawczego współdziałania ekstraneusa w popełnieniu przestępstwa indywidualnego w praktyce orzeczniczej, jak i chociażby większościowego stanowiska przedstawicieli doktryny prawa karnego. Zwiększenie zakresu stosowania reguły odnoszonej do odpowiedzialności ekstraneusa za podżeganie i po-

propozycji rozwiązania tego zagadnienia, z których pierwsza, zawarta w projekcie z 1994 r., odnosiła się do wszystkich form współdziałania w popełnieniu przestępstwa, lecz wyłącznie w odniesieniu do przestępstw indywidualnych właściwych, druga — do wszystkich postaci współdziałania w odniesieniu do wszystkich przestępstw indywidualnych, z wyłączeniem przestępstw indywidualnych niewłaściwych mających postać typów uprzywilejowanych. Zob. w tej kwestii R. Dębski, op. cit., s. 13.

18 Konsekwencją sporów dotyczących kwestii odpowiedzialności za podżeganie i pomocnictwo do przestępstwa indywidualnego, prowadzonych od chwili wejścia w życie k.k. z 1969 r. aż do końca lat 60., było wprowadzenie do k.k. z 1969 r. regulacji zawartej w art. 19 § 2 k.k., jednoznacznie przesądzającej o możliwości pociągania podżegacza i pomocnika do odpowiedzialności za przestępstwo indywidualne oraz określającej podstawy odpowiedzialności za podżeganie i pomocnictwo do przestępstwa indywidualnego, tj. wskazującej, że warunkiem takiej odpowiedzialności jest skierowanie czynności nakłaniania lub ułatwiania na osobę bezpośredniego wykonawcy (sprawcę) mającego cechy wymagane przez ustawę od sprawcy przestępstwa indywidualnego oraz wiedza podżegacza i pomocnika o tym, że bezpośredni wykonawca ma te właściwości. Z kolei konsekwencją sporów dotyczących kwestii odpowiedzialności ekstraneusa za współsprawstwo lub sprawstwo kierownicze w popełnieniu przestępstwa indywidualnego było wprowadzenie do k.k. z 1997 r. regulacji zawartej w art. 21 § 2 k.k., która zgodnie z założeniami twórców tego rozwiązania oraz stosunkowo powszechnym przekonaniem teoretyków prawa karnego materialnego jednoznacznie przesądzała możliwość ponoszenia przez ekstraneusa odpowiedzialności za współsprawstwo lub sprawstwo kierownicze przestępstwa indywidualnego (zarówno właściwego, jak i niewłaściwego) oraz określała przesłanki takiej odpowiedzialności, tj. cechowanie się sprawcy właściwościami wymaganymi ustawą od sprawcy przestępstwa indywidualnego oraz wiedza sprawczo współdziałającego (tj. współsprawcy lub sprawcy kierowniczego) o spełnieniu tego warunku przez sprawcę. Jakkolwiek twórcy regulacji zawartej w art. $21 \S 2$ k.k. pozostawali w przekonaniu, że nie tylko służyć będzie rozwiązaniu sporów wokół odpowiedzialności za współsprawstwo lub sprawstwo kierownicze ekstraneusa w popełnieniu przestępstwa indywidualnego, lecz także co do tego, że treść normatywna art. $21 \S 2$ k.k. jest jednoznaczna, to jednak już tylko pobieżne wejrzenie w zawartość treściową art. $21 \S 2$ k.k. wywoływać może w obu zakresach poważne wątpliwości. 
mocnictwo do przestępstwa indywidualnego na sprawcze postaci współdziałania nastąpiło w pewnym sensie w sposób zaskakujący i bez wątpienia niepoprzedzony poważniejszą teoretyczną analizą ${ }^{19}$. Być może brak jednoznacznego, a co najmniej większościowego, stanowiska doktryny co do kryminalnopolitycznego uzasadnienia pociągania do odpowiedzialności karnej ekstraneusa za sprawcze współdziałanie w popełnieniu przestępstwa indywidualnego oraz ewentualnego sposobu ustawowego rozstrzygnięcia tej kwestii stanowił zasadniczy powód tego, że wprowadzenie do systemu obowiązującego prawa karnego rozwiązania przewidzianego w art. $21 \S 2$ k.k. bynajmniej nie spowodowało chociażby częściowego ujednolicenia poglądów, wręcz przeciwnie - stało się podstawą dodatkowych kontrowersji. Do kwestii spornych związanych z kryminalnopolitycznymi, teoretycznymi i dogmatycznymi aspektami odpowiedzialności ekstraneusa za współdziałanie w popełnieniu przestępstwa indywidualnego dodano czysto dogmatyczne problemy związane z wykładnią regulacji zawartej w art. $21 \S 2$ k.k., które często prezentowane są w szerszym kontekście teoretycznych analiz dotyczących współdziałania ekstraneusa w popełnieniu przestępstwa indywidualnego.

W konsekwencji zamiast uporządkowania kwestii odpowiedzialności ekstraneusa za współdziałanie w popełnieniu przestępstwa indywidualnego, wprowadzenie regulacji zawartej w art. $21 \S 2$ k.k. z 1997 r. jedynie powiększyło podstawy, zakres i skalę sporów. W świetle aktualnego stanu polskiego piśmiennictwa w sferze odpowiedzialności ekstraneusa za współdziałanie w popełnieniu przestępstwa indywidualnego kwestionowane jest w zasadzie wszystko. Kontrowersje i rozbieżność stanowisk dotyczą problemów związanych z płaszczyzną kryminalnopolityczną, teoretyczną, dogmatyczną i normatywną. Z perspektywy kryminalnopolitycznej kwestionuje się zasadność i możliwość konstruowania podstaw odpowiedzialności ekstraneusa za współsprawstwo w popełnieniu przestępstwa indywidualnego ${ }^{20}$. Przedmiotem sporów i kontrowersji są zagadnienia związane z konstrukcyjnymi właściwościami regulacji współdziałania, w szczególności zaś znaczeniem i funkcją art. $18 \mathrm{k} . \mathrm{k}$. w procesie rekonstrukcji norm sankcjonowanej i sankcjonującej charakteryzujących płaszczyznę bezprawności i karalności po-

19 Można wręcz uznać, że regulacja zawarta w art. 21 § 2 k.k. jest jednym w wielu przejawów intuicjonizmu twórców kolejnych projektów nowelizacji, przekonanych, że każda idea, która pojawia się w kręgu oficjalnie powołanych do opracowywania projektów zmian normatywnych, zasługuje na przekształcenie w zapisy ustawowe. Karykaturalną postać to zgubne przeświadczenie instytucjonalnych legislatorów przybrało w opracowanej przez Komisję Kodyfikacyjną Prawa Karnego przy Ministrze Sprawiedliwości RP nowelizacji z dnia 20 lutego 2015 r.

20 Zob. w szczególności stanowisko T. Kaczmarka, Recenzja ksiązki..., s. 102 n.; idem, Sporne problemy..., s. 272 n. Interesujące jest, że także zwolennicy odpowiedzialności ekstraneusa za sprawcze i niesprawcze postaci współdziałania przy przestępstwie indywidualnym prezentują stanowisko wykluczające możliwość ponoszenia odpowiedzialności przez ekstraneusa za współsprawstwo przestępstwa indywidualnego, oparte na specyficznym rozumieniu istoty współsprawstwa. Zob. w tej kwestii w szczególności Ł. Pohl, op. cit., s. 187 n. 
szczególnych odmian sprawczego współdziałania ${ }^{21}$. Nieklarowny jest teoretyczny opis i dogmatyczna charakterystyka sprawstwa jako centralnej postaci popełnienia przestępstwa w odniesieniu do przestępstw o zawężonym kręgu podmiotów ${ }^{22}$. Fundamentalne rozbieżności ujawniają się w związku z procesem rekonstrukcji norm: sankcjonowanej i sankcjonującej, charakteryzujących przestępstwa o zawężonym kręgu podmiotów ${ }^{23}$. Sporne są wreszcie kwestie związane ze znaczeniem i funkcją art. $21 \S 2$ k.k., sięgające zagadnień podstawowych, w tym związków tego przepisu z art. 18 k.k., jego zakresu zastosowania ${ }^{24}$, poprawności ujęcia ${ }^{25}$, wreszcie - potrzeby istnienia tego typu regulacji w kodeksie karnym ${ }^{26}$.

$\mathrm{Z}$ tego zdaje się wynikać, że w istocie $\mathrm{w}$ odniesieniu do rozwiązań zawartych w k.k. z 1969 r. w art. 19 § 2 k.k., w k.k. zaś z 1997 r. w art. 21 § 2 k.k. poza wskazaniem form współdziałania, do jakich odnosił się najpierw art. 19 § 2 k.k. oraz aktualnie odnosi się art. $21 \S 2$ k.k. z 1997 r., w zasadzie nie przedstawiono szerszej teoretycznej podstawy wyrażanych przez te przepisy regulacji, nie wyjaśniono także w pełni ich dogmatycznej charakterystyki oraz pełnionych funkcji. Trzeba podkreślić, że w okresie obowiązywania kodeksu karnego z 1969 r. nie przedstawiono szerszego uzasadnienia relacji art. 19 § 2 k.k. z 1969 r. do określającego podstawy odpowiedzialności za podżeganie i pomocnictwo art. 18 k.k., nie wyjaśniono także relacji, w jakich pozostawał art. 19 § 2 k.k. do regulacji zawartej w art. 16 k.k. z 1969 r. dotyczącej sprawstwa pojedynczego (bezpośredniego), współsprawstwa i sprawstwa kierowniczego. Stan ten zmienił się zasadniczo po wejściu w życie art. 21 § 2 k.k. z 1997 r., kiedy w polskim piśmiennictwie przedstawiono i powszechnie przyjęto stanowisko wskazujące na samodzielny charakter znamion podżegania i pomocnictwa, tworzących na gruncie polskiego systemu prawa karnego odrębne typy czynu zabronionego w każdym przypadku - a więc zarówno $\mathrm{w}$ razie powiązania podżegania i pomocnictwa $\mathrm{z}$ typem przestępstwa powszechnego w formie sprawstwa pojedynczego (bezpośredniego), jak i powiązania podżegania i pomocnictwa $\mathrm{z}$ typem przestępstwa indywidualnego w formie sprawstwa pojedynczego (bezpośredniego) — o powszechnej charakterystyce podmiotu odpowiedzialności karnej za podżeganie i pomocnictwo ${ }^{27}$. To

${ }^{21}$ Zob. w szczególności Ł. Pohl, Prawo karne. Wykład części ogólnej, Warszawa 2012, s. 120 n.; Ł. Pilarczyk, Analiza odpowiedzialności karnej ekstraneusa za przestępne współdziatanie w odniesieniu do podżegania i pomocnictwa, „Ius Novum” 2014, nr 4, s. 75 n.; Ł. Pilarczyk, Postulaty..., s. 94 n.

22 Zob. m.in. A. Wąsek, op. cit., s. 147 n.; P. Kardas, Teoretyczne podstawy..., s. 407 n.; A. Liszewska, Współdziałanie..., s. 34 n.; Ł. Pohl, Wykład..., s. 187 n.

23 Zob. w szczególności Ł. Pohl, Wykład..., s. 119 n. oraz s. 187 n.

24 Zob. w szczególności Ł. Pohl, Struktura normy sankcjonowanej w prawie karnym. Zagadnienia ogólne, Poznań 2007, s. 173 n.; idem, Wykład..., s. 172 n.; Ł. Pilarczyk, Postulaty..., s. 97 n.

25 Zob. w szczególności A. Liszewska, Odpowiedzialność..., s. 5 n.

${ }^{26}$ Zob. w szczególności Ł. Pohl, Wyktad..., s. 187 n.; Ł. Pilarczyk, Postulaty..., s. 97 n.

27 Zob. w tej kwestii P. Kardas, Teoretyczne podstawy..., s. 560 n. Stanowisko to zostało powszechnie zaaprobowane w doktrynie i orzecznictwie. 
twierdzenie stanowiło podstawę do stosunkowo szeroko akceptowanego aktualnie stanowiska o braku normatywnego znaczenia regulacji zawartej w art. $21 \S 2$ k.k. dla kwestii odpowiedzialności ekstraneusa za podżeganie i pomocnictwo do przestępstwa indywidualnego ${ }^{28}$. Zarazem w odniesieniu do problemu odpowiedzialności ekstraneusa za sprawcze postaci współdziałania w popełnieniu przestępstwa indywidualnego na gruncie regulacji kodeksu karnego z 1997 r. zachowano tradycyjne twierdzenie o niezbędności istnienia w kodeksie szczególnej regulacji odnoszącej się do tej kwestii, której upatruje się w art. $21 \S 2$ k.k. Jednak poza wskazaniem, że podstawą odpowiedzialności współdziałającego sprawczo ekstraneusa w popełnieniu przestępstwa indywidualnego jest art. $21 \S 2$ k.k., w piśmiennictwie nie przedstawiono bardziej rozbudowanej koncepcji objaśniającej relacje, w jakich pozostają przepisy art. 18 k.k. i art. $21 \S 2$ k.k. W szczególności nie stanowiło przedmiotu rozważań normatywne znaczenie regulacji umożliwiającej pociąganie do odpowiedzialności karnej esktraneusa za sprawcze współdziałanie w popełnieniu przestępstwa indywidualnego. Paradoksalnie, wbrew powszechnemu przekonaniu, konieczność wyjaśnienia podstawy odpowiedzialności ekstraneusa za sprawcze współdziałanie w popełnieniu przestępstwa indywidualnego wiąże się nie tylko z podstawami odpowiedzialności ekstraneusa, lecz — w pewnych układach procesowych - także intraneusa. Wystarczy odwołać się do konstrukcji współsprawstwa dopełniającego, stosowanej do układu sprawczego współdziałania intraneusa oraz ekstraneusa, by dostrzec, że brak podstaw do pociągnięcia do odpowiedzialności karnej za sprawcze współdziałanie w popełnieniu przestępstwa indywidualnego ekstraneusa rodzić może poważne wątpliwości co do odpowiedzialności intraneusa za tę sprawczą postać współdziałania. Jeśli współsprawstwo dopełniające prowadzić ma do wzajemnego przypisania każdemu ze współsprawczo współdziałających tego, co zrealizowali pozostali, to nie jest wcale oczywiste, na jakiej podstawie przypisać intraneusowi to, co uczynił współdziałający z nim ekstraneus. Podobne komplikacje pojawiają się w odniesieniu do - sygnalizowa-

${ }^{28}$ Koncepcja samodzielności znamion typów podżegania i pomocnictwa o powszechnej charakterystyce podmiotu odpowiedzialności karnej zarówno wówczas, gdy podżeganie i pomocnictwo powiązane jest z typem przestępstwa powszechnego, jak i gdy łączy się z typem przestępstwa indywidualnego (właściwego lub niewłaściwego), przeniesiona na grunt regulacji z art. 19 § 2 k.k. z 1969 r. oznaczałaby, że przepis ten w istocie wyrażał przesłanki odpowiedzialności karnej za podżeganie i pomocnictwo wynikające z treści art. 18 k.k. z 1969 r. Tym samym mógł być uznany za ustawowe superfluum, wyrażające w sposób jednoznaczny stanowisko ustawodawcy co do możliwości pociągania ekstraneusa za podżeganie i pomocnictwo do przestępstwa indywidualnego (właściwego lub niewłaściwego), co stanowiło przedmiot sporów w okresie obowiązywania k.k. z 1932 r. Koncepcja ta stanowić może także teoretyczne i dogmatyczne uzasadnienie stanowiska prezentowanego w okresie międzywojennym, dopuszczającego możliwość odpowiedzialności ekstraneusa za podżeganie i pomocnictwo do przestępstwa indywidualnego (właściwego i niewłaściwego), a także podstawę kwestionowania poprawności poglądów J. Makarewicza, odrzucającego możliwość pociągania do odpowiedzialności karnej za podżeganie i pomocnictwo do przestępstwa indywidualnego zarówno intraneusa, jak i ekstraneusa. 
nych już — konstrukcji sprawstwa kierowniczego oraz sprawstwa polecającego, w szczególności w odniesieniu do sytuacji, gdy kierujący lub wydający polecenie ma właściwości wymagane od sprawcy przestępstwa o zawężonym kręgu podmiotów, bezpośredni wykonawca zaś, tj. osoba kierowana lub adresat polecenia, cech takich nie ma. W takich wypadkach odpowiedzialność za sprawstwo lub sprawcze współdziałanie w popełnieniu przestępstwa indywidualnego musiałaby się opierać na właściwościach kierującego lub wydającego polecenie, co w istocie zdaje się wskazywać, że zasadniczo chodzi tutaj o popełnienie przestępstwa przez kierującego lub wydającego polecenie intraneusa za pośrednictwem innej osoby, mającej status ekstraneusa. To zaś jest zasadniczo możliwe w kontekście konstrukcji sprawstwa pośredniego. Co prawda powszechnie przyjmuje się, że sprawstwo kierownicze oraz sprawstwo polecające to w polskim systemie prawa karnego odpowiedniki sprawstwa pośredniego znanego ustawodawstwu i doktrynie niemieckiej ${ }^{29}$, jednak nie można tracić z pola widzenia, że art. $18 \S 1$ k.k. zdanie trzecie i czwarte przewiduje szczególną podstawę odpowiedzialności kierującego lub wydającego polecenie, jaką jest w przypadku sprawstwa kierowniczego „kierowanie wykonaniem czynu zabronionego" przez inną osobę, w wypadku zaś sprawstwa polecającego - „wydanie polecenia wykonania czynu zabronionego przez inną osobę". W wypadku przestępstwa indywidualnego — właściwego lub niewłaściwego - wykonanie czynu zabronionego wymaga charakteryzowania się przez bezpośredniego wykonawcę cechami wymaganymi ustawą od sprawcy przestępstwa indywidualnego. Ich brak, z czym mamy do czynienia w omawianym w tym miejscu układzie kierowania lub wydania polecenia wykonania czynu zabronionego ekstraneusowi, zdaje się wykluczać możliwość spełnienia określonego w art. $18 \S 1$ k.k. zdanie trzecie i czwarte warunku, a tym samym mocno komplikuje kwestie odpowiedzialności karnej intraneusa za sprawcze współdziałanie w popełnieniu przestępstwa indywidualnego ${ }^{30}$. Zagadnień spornych w zakresie odpowiedzialności intraneusa za sprawcze współdziałanie w popełnieniu przestępstwa indywidualnego z ekstraneusem jest znacznie więcej.

Przystępując do dalszych rozważań dotyczących problemu podstaw odpowiedzialności ekstraneusa za sprawcze współdziałanie w popełnieniu przestępstwa

${ }^{29}$ Co do konstrukcji sprawstwa pośredniego w niemieckim systemie prawa karnego zob. szerzej P. Kardas, Teoretyczne podstawy..., s. $248 \mathrm{n}$.

30 Trzeba wskazać, że w doktrynie stosunkowo powszechnie przyjmuje się, że pojęcie ,sprawca", użyte w treści art. $21 \S 2$ k.k., odnosi się do każdego współdziałającego, a więc także sprawcy kierowniczego lub sprawcy polecającego, co tworzy podstawę tezy, iż w opisanych przypadkach kwestie podstaw odpowiedzialności intraneusa za sprawcze współdziałanie rozwiązuje właśnie art. $21 \S 2$ k.k. Stanowisko to może, jak starano się wskazać, wywoływać jednak poważne wątpliwości, związane nie tyle i nie tylko z treścią art. 21 § k.k., ile z właściwościami konstrukcyjnymi sprawstwa kierowniczego i sprawstwa polecającego. Warto dodać, że owe zastrzeżenia są całkowicie niezależne od tego, czy sprawstwo kierownicze i sprawstwo polecające uznaje się za akcesoryjne czy też nieakcesoryjne odmiany współdziałania. — P. Kardas [w:] G. Bogdan et al., op. cit., s. 407. 
indywidualnego, należy wskazać, że z teoretycznego punktu widzenia możliwe jest ukształtowanie regulacji dotyczącej podstaw odpowiedzialności ekstraneusa za współdziałanie w popełnieniu przestępstwa indywidualnego w kontekście dwu przeciwstawnych modeli ${ }^{31}$.

Pierwszy opiera się na założeniu, że ustawowe uregulowanie kwestii odpowiedzialności ekstraneusa za współdziałanie w popełnieniu przestępstwa indywidualnego wymaga modyfikacji tej części znamion charakteryzujących przestępstwo o zawężonym kręgu podmiotów sprawczych, która określa cechy wymagane przez ustawę od podmiotu odpowiedzialności karnej, i stanowi element konstytuujący typy przestępstw indywidualnych w formie sprawstwa pojedynczego (bezpośredniego). Stworzenie podstaw odpowiedzialności ekstraneusa za współdziałanie w popełnieniu przestępstwa o zawężonym kręgu podmiotów wymaga modyfikacji znamion dotyczących podmiotu odpowiedzialnego za współdziałanie w popełnieniu przestępstwa indywidualnego, prowadzących do przekształcenia typu przestępstwa indywidualnego $\mathrm{w}$ formie sprawstwa pojedynczego (bezpośredniego) w przestępstwo powszechne w każdej formie współdziałania lub tylko w odniesieniu do niektórych odmian sprawczego lub niesprawczego współdziałania.

Drugi z modeli polega na wprowadzeniu do ustawy szczególnego przepisu określającego przesłanki, których aktualizacja w określonym układzie procesowym stanowić będzie podstawę do przyjęcia odpowiedzialności ekstraneusa za współdziałanie w popełnieniu przestępstwa indywidualnego we współdziałaniu z intraneusem, przy zachowaniu bez zmian ustawowej charakterystyki podmiotu odpowiedzialności karnej za przestępstwo indywidualne w odniesieniu do postaci współdziałania. W pewnym uproszczeniu ten model określania w ustawie podstaw odpowiedzialności za współdziałanie ekstraneusa w popełnieniu przestępstwa indywidualnego nie prowadzi do modyfikacji ustawowej charakterystyki podmiotu odpowiedzialności karnej w przypadku współdziałania w popełnieniu przestępstwa indywidualnego, które także w odniesieniu do znanych danemu systemowi prawa karnego postaci współdziałania zachowuje status przestępstwa indywidualnego. Opiera się natomiast na wskazaniu w ustawie przesłanek, których spełnienie pozwala na pociągnięcie do odpowiedzialności karnej ekstraneusa za współdziałanie $\mathrm{z}$ intraneusem $\mathrm{w}$ popełnieniu przestępstwa indywidualnego. Posługując się swoistym skrótem myślowym, z uwagi na zachowanie w przypadkach współdziałania w popełnieniu przestępstwa indywidualnego charakteru typu czynu zabronionego o zawężonym kręgu podmiotów, także w odniesieniu do znanych danemu systemowi prawa karnego postaci współdziałania, omawiana koncepcja (model) sprowadza się do określenia w ustawie w szczególnym przepisie przesłanek, których spełnienie w realiach konkretnego stanu faktycznego prowadzi do przyjęcia specyficznej fikcji spełnienia przez ekstraneusa ustawowych przesłanek

31 O koncepcji tej pisałem już wcześniej w opracowaniu P. Kardas, Typy zmodyfikowane... 
odpowiedzialności za przestępstwo o zawężonym kręgu podmiotów zdatnych do ponoszenia odpowiedzialności karnej. Innymi słowy wprowadzenia do ustawy przesłanek, których spełnienie przy zachowaniu niezmienionego w odniesieniu do podmiotu odpowiedzialności karnej typu współdziałania o indywidualnej charakterystyce podmiotu odpowiedzialności karnej pozwoli pociągnąć esktraneusa do odpowiedzialności karnej za współdziałanie w popełnieniu przestępstwa indywidualnego, a więc — innymi słowy — skutkującej swoistym ,przekształcenia ekstraneusa w intraneusa" ${ }^{\prime 2}$, przy zachowaniu indywidualnego charakteru przestępstwa we wszystkich postaciach współdziałania.

Pierwszy ze wskazanych modeli teoretycznych ustawowego rozwiązywania kwestii odpowiedzialności ekstraneusa za współdziałanie w popełnieniu przestępstwa indywidualnego opiera się na wprowadzeniu do ustawy karnej szczególnej regulacji stanowiącej podstawę do modyfikacji ustawowej charakterystyki znamion odnoszących się do podmiotu odpowiedzialności karnej w przypadku współdziałania, prowadząc do przekształcenia w trakcie procesu wykładni uwzględniającego taki szczególny przepis typu indywidualnego, o zawężonym kręgu podmiotów w formie sprawstwa pojedynczego, w typ powszechny w przypadku współdziałania. Model ten może przejawiać się w dwóch odmianach — szerokiej i wąskiej. Odmiana szeroka opiera się na przekształceniu charakterystyki podmiotu sprawczego w przypadku współdziałania w popełnieniu przestępstwa indywidualnego w charakterystykę odpowiadającą opisowi podmiotu sprawczego w przypadku tzw. powszechnych. Pociągnięcie do odpowiedzialności karnej ekstraneusa za współdziałanie w popełnieniu przestępstwa indywidualnego nie wymaga zatem spełnienia (wykazywania) żadnych dodatkowych okoliczności, poza tym, iż w popełnieniu przestępstwa indywidualnego musi brać udział co najmniej jedna osoba mająca cechy wymagane od sprawcy przestępstwa o zawężonym kręgu podmiotów odpowiedzialności karnej ${ }^{33}$. Odmiana wąska opiera się, identycznie jak przedstawiona wyżej odmiana szeroka, na przekształceniu charakterystyki podmiotu sprawczego w przypadku współdziałania w popełnieniu przestępstwa

32 W taki sposób zdawał się rekonstruować zasadę, na której oparte było rozwiązanie z art. 19 $\S 2$ k.k., A. Wąsek — wykluczając możliwość odpowiedzialności za współsprawstwo przestępstwa indywidualnego ekstraneusa, wskazywał, że charakterystyczne dla współsprawstwa dopełnianie się czynów współdziałających ,nie może pójść tak daleko, że przekształciłoby ekstraneusa w intraneusa" - A. Wąsek, op. cit., s. 147. Zob. też uwagi Ł. Pilarczyka, Postulaty..., s. 106.

33 Warunek ten wynika z istoty podstaw odpowiedzialności karnej za przestępstwa indywidualne, właściwe i niewłaściwe, których znamiona mogą zostać zrealizowane tylko przez osobę mającą cechy wymagane dla podmiotu odpowiedzialności karnej. Brak w konfiguracji wieloosobowej chociażby jednej takiej osoby powoduje, iż nie jest możliwe wypełnienie znamion przestępstwa indywidualnego w żadnym układzie, niezależnie od tego jaką konstrukcję przewidziano by w ustawie w odniesieniu do rozstrzygania kwestii odpowiedzialności ekstraneusa za współdziałanie w popełnieniu przestępstwa indywidualnego. Współdziałanie dwóch lub więcej ekstraneusów w kontekście przesłanek odpowiedzialności karnej za przestępstwo indywidualne pozostaje zawsze, z punktu widzenia charakterystyki podmiotu odpowiedzialności karnej, prawnokarnie irrelewantne. 
indywidualnego w charakterystykę odpowiadającą opisowi podmiotu sprawczego, w przypadku przestępstw powszechnych powiązaną z określeniem dodatkowych przesłanek, których spełnienie warunkuje pociągnięcie do odpowiedzialności karnej ekstraneusa za współdziałanie w popełnieniu przestępstwa indywidualnego, a których brak w realiach konkretnego stanu faktycznego odpowiedzialność taką wyłącza. Z uwagi na występowanie $\mathrm{w}$ drugiej z przedstawionych $\mathrm{w}$ tym miejscu odmian dodatkowych przesłanek odpowiedzialności ekstraneusa za współdziałanie w popełnieniu przestępstwa indywidualnego została ona określona jako odmiana wąska, odmiana zaś pozbawiona tych warunków - jako odmiana szeroka. Różnica między tymi sposobami uregulowania kwestii odpowiedzialności karnej ekstraneusa za współdziałanie w popełnieniu przestępstwa indywidualnego dotyczy zakresu odpowiedzialności — szerokiej i w zasadzie nieograniczonej w przypadku wykorzystania odmiany pierwszej, określanej jako szeroka — oraz ograniczonej, obejmującej tylko niektóre przypadki współdziałania ekstraneusa w popełnieniu przestępstwa indywidualnego w razie wykorzystania odmiany określonej jako wąska.

Model drugi nie modyfikuje znamion typu w formie współdziałania, który w każdym przypadku zachowuje charakter przestępstwa indywidualnego o zawężonym kręgu podmiotów odpowiedzialności karnej, stwarza jednak podstawy do przypisania odpowiedzialności za współdziałanie w popełnieniu przestępstwa indywidualnego ekstraneusowi, opierając się na wynikającej z odpowiedniej regulacji fikcji spełnienia właściwości wymaganych od sprawcy przez ekstraneusa.

Pierwsze ze wskazanych teoretycznych rozwiązań można zrealizować poprzez odpowiednie ukształtowanie przepisu ogólnego, określającego podstawy odpowiedzialności za postaci współdziałania, lub poprzez wprowadzenie do ustawy szczególnego rozwiązania modyfikującego ustawową charakterystykę podmiotu w przypadku przestępstw indywidualnych. Rozwiązanie oparte na odpowiednim ukształtowaniu przepisów ogólnych określających podstawy odpowiedzialności za współdziałanie w popełnieniu przestępstwa indywidualnego co do zasady opiera się na przedstawionej wyżej szerokiej odmianie tej koncepcji. Ten sposób ustawowej regulacji podstaw odpowiedzialności za współdziałanie ma ogólny charakter, określa bowiem charakterystykę podmiotu odpowiedzialności karnej w odniesieniu do znanych danemu systemowi prawa karnego postaci współdziałania, które w każdym przypadku opisują podmiot odpowiedzialności karnej jako podmiot powszechny. Choć znaczenie tego rozwiązania ujawnia się przede wszystkim w odniesieniu do kwestii odpowiedzialności za współdziałanie ekstraneusa w popełnieniu przestępstwa indywidualnego, to jednak określa ono podmiot w każdym przypadku, a więc także w razie współdziałania w popełnieniu przestępstwa powszechnego. Regulacja wykorzystująca wprowadzenie do ustawy szczególnego przepisu modyfikującego ustawową charakterystykę podmiotu odpowiedzialności karnej w razie współdziałania w popełnieniu przestępstwa indywidualnego co do 
zasady opiera się na wykorzystaniu opisanej wąskiej odmiany analizowanej koncepcji. Ten sposób ustawowego rozwiązania kwestii podstaw odpowiedzialności karnej za współdziałanie ekstraneusa w popełnieniu przestępstwa indywidualnego odnosi się wyłącznie do tej kwestii ${ }^{34}$.

Drugie ze wskazanych teoretycznych rozwiązań wymaga wprowadzenia do ustawy szczególnego przepisu stanowiącego podstawę przyjęcia, iż ekstraneus traktowany będzie na potrzeby odpowiedzialności karnej jako osoba mająca cechy wymagane od sprawcy przestępstwa indywidualnego przy spełnieniu określonych w ustawie warunków.

Rozwiązanie oparte na modyfikacji znamion charakteryzujących sprawcę przestępstwa indywidualnego w przypadkach typów określających podstawy odpowiedzialności za sprawcze i niesprawcze odmiany współdziałania ma charakter uniwersalny, albowiem opiera się na przekształceniu przestępstwa indywidualnego $\mathrm{w}$ formie sprawstwa pojedynczego $\mathrm{w}$ przestępstwo powszechne $\mathrm{w}$ postaci współdziałania. Stwarza tym samym możliwość i konieczność pociągania ekstraneusa do odpowiedzialności karnej za sprawcze i niesprawcze współdziałanie w przypadku każdego przestępstwa indywidualnego - właściwego i niewłaściwego, w drugim z obszarów — zarówno przestępstwa określającego typ kwalifikowany, jak i typ uprzywilejowany. Trzeba jednak podkreślić, że także w tym modelu możliwe jest zróżnicowanie podstaw odpowiedzialności ekstraneusa za współdziałanie w popełnieniu przestępstwa indywidualnego i w konsekwencji np. odmienne ukształtowanie charakterystyki poszczególnych postaci współdziałania w zakresie podmiotu odpowiedzialności karnej, prowadzące do zróżnicowania odpowiedzialności za współdziałanie w popełnieniu przestępstwa indywidualnego w zależności od postaci współdziałania ${ }^{35}$.

${ }^{34} \mathrm{Z}$ reguły powszechne określenie podmiotu odpowiedzialności karnej dla postaci współdziałania połączone jest ze wskazaniem dodatkowych przesłanek, których spełnienie warunkuje odpowiedzialność ekstraneusa za współdziałanie w popełnieniu przestępstwa indywidualnego. Zasadniczo wykorzystuje się w tym modelu przesłanki przedmiotowe (obiektywne) i subiektywne, tj. na płaszczyźnie przedmiotowej w postaci warunku współdziałania ekstraneusa z intranesuem, na płaszczyźnie zaś subiektywnej — warunek świadomości ekstraneusa, że współdziała w z intraneusem $\mathrm{w}$ popełnieniu przestępstwa indywidualnego. W pewnym zakresie na tej koncepcji oparta jest regulacja zawarta w art. $21 \S 2$ k.k., choć przepis ten nie modyfikuje sposobu ustawowego określenia podmiotu odpowiedzialności karnej w przypadku współdziałania w popełnieniu przestępstwa indywidualnego.

35 Wedle dominującego w polskim piśmiennictwie i orzecznictwie stanowiska ten sposób wykorzystał ustawodawca, regulując zagadnienie odpowiedzialności karnej za współdziałanie ekstraneusa w popełnieniu przestępstwa indywidualnego w k.k. z 1997 r. W odniesieniu do niesprawczych postaci współdziałania (podżegania i pomocnictwa) wykorzystano model prowadzący do modyfikacji ustawowej charakterystyki podmiotu odpowiedzialności karnej w typach podżegania i pomocnictwa, które z uwagi na treść art. 18 § 2 i 3 k.k. mają w każdym przypadku postać tzw. typów powszechnych, tj. określających podmiot odpowiedzialności karnej za podżeganie i pomocnictwo jako podmiot powszechny, także w sytuacji powiazania konstrukcji podżegania i po- 
Z kolei rozwiązanie oparte na wprowadzeniu do ustawy szczególnego przepisu odnoszącego się do problemu odpowiedzialności karnej ekstraneusa za współdziałanie przy przestępstwie indywidualnym umożliwia zróżnicowanie zakresu tej odpowiedzialności i ukształtowanie jej odmiennie dla poszczególnych odmian przestępstw indywidualnych lub zróżnicowanie zakresu tej odpowiedzialności dla poszczególnych postaci współdziałania.

Nie wydaje się wykluczone także łączne wykorzystanie obu zarysowanych tu modeli regulowania kwestii podstaw odpowiedzialności karnej za współdziałanie ekstraneusa w popełnieniu przestępstwa indywidualnego, umożliwiające zróżnicowanie zakresu i podstaw odpowiedzialności karnej albo w zależności od postaci współdziałania (tj. oparcie regulacji ustawowej na odmiennej koncepcji w odniesieniu do sprawczego oraz niesprawczego współdziałania) lub zróżnicowanie zakresu odpowiedzialności na podstawie odmiennych zasad dotyczących poszczególnych typów (odmian) przestępstw indywidualnych (np. odmienne ukształtowanie podstaw odpowiedzialności w odniesieniu do współdziałania ekstraneusa w popełnieniu przestępstwa indywidualnego właściwego oraz odmienne w odniesieniu do współdziałania ekstraneusa w popełnieniu przestępstwa indywidualnego niewłaściwego, lub też tylko niektórych odmian przestępstwa indywidualnego niewłaściwego, np. typów zmodyfikowanych uprzywilejowanych ${ }^{36}$ ).

Wybór określonego rozwiązania ustawowego poprzedzać powinno prawidłowe rozpoznanie teoretycznych możliwości kształtowania zakresu odpowiedzialności karnej za współdziałanie w popełnieniu przestępstwa indywidualnego, określenie charakterystycznych cech i konsekwencji wynikających z wykorzystania poszczególnych modeli, prawidłowe rozpoznanie poszczególnych odmian przestępstw indywidualnych, wreszcie — wybór określonej opcji politycznokryminalnej oraz dostosowanie właściwych mechanizmów prawnych opartych na określonych modelach. Spełnienie tych warunków stwarza podstawy do ukształtowania ustawowej regulacji w sposób spójny, umożliwia zastosowanie adekwatnej techni-

mocnictwa $\mathrm{z}$ typem indywidualnym w formie sprawstwa pojedynczego (bezpośredniego). Z kolei w odniesieniu do sprawczego współdziałania w popełnieniu przestępstwa indywidualnego przyjęto zasadę, wedle której regulacja zawarta w art. 18 § 1 k.k. nie modyfikuje charakterystyki podmiotu odpowiedzialności karnej w odniesieniu do typów określających znamiona sprawczych postaci współdziałania, czego konsekwencją jest zachowanie także w tych wypadkach indywidualnego charakteru danego typu przestępstwa w formie sprawczych postaci współdziałania. Możliwości pociągnięcia ekstraneusa do odpowiedzialności karnej za współdziałanie w popełnieniu przestępstwa indywidualnego wymagają zatem wprowadzenia do kodeksu karnego szczególnej regulacji, opartej na drugim z opisanych powyżej modeli teoretycznych, której funkcję pełni aktualnie art. $21 \S 2$ k.k.

36 Powszechnie przyjmuje się, że w taki właśnie sposób uregulowane zostały podstawy odpowiedzialności ekstraneusa za współdziałanie w popełnieniu przestępstwa indywidualnego w polskim kodeksie karnym z 1997 r. Zob. w tej kwestii w szczególności P. Kardas, Teoretyczne podstawy..., s. 592; R. Dębski, op. cit., s. 17-18; A. Zoll, Podstawy teoretyczne regulacji wspótdziałania przestęnego w projekcie kodeksu karnego, PiP 1995, nr 6, s. 39; A. Liszewska, Odpowiedzialność..., s. 17 n. Zob. też J. Giezek [w:] J. Giezek, N. Kłączyńska, G. Łabuda, op. cit., s. 185-186. 
ki legislacyjnej, ostatecznie zaś wykładni wprowadzonych do systemu przepisów gwarantującej realizację przyjętych przez ustawodawcę celów. Analiza przyjętych przez polskiego ustawodawcę regulacji dotyczących współdziałania w popełnieniu przestępstwa indywidualnego wskazuje, że kształtując poszczególne rozwiązania, nie zawsze brano pod uwagę wskazane warunki poprawnej i skutecznej legislacji. Nie w każdym przypadku przed wprowadzeniem do kodeksu karnego określonych rozwiązań przeprowadzono właściwie zakreślone analizy teoretyczne oraz dokonywano oceny kryminalnopolitycznych konsekwencji określonych regulacji. Mankamenty we wskazanych obszarach w sposób szczególnie dotkliwy ujawniają się w zakresie podstaw odpowiedzialności za sprawcze postaci współdziałania, co dotyczy zwłaszcza zagadnienia możliwości pociągania do odpowiedzialności karnej ekstraneusa współdziałającego w popełnieniu przestępstwa indywidualnego. Problem teoretycznych podstaw i technicznolegislacyjnej poprawności regulacji dotyczącej podstaw odpowiedzialności za sprawstwo oraz sprawcze postaci współdziałania jest zresztą zdecydowanie szerszy i odnosi się do wielu zagadnień o podstawowym wręcz znaczeniu. W przeciwieństwie do niesprawczych postaci współdziałania w sferze sprawstwa i sprawczych postaci współdziałania brakuje w zasadzie podstawowych analiz teoretycznych oraz rozważań dotyczących modeli odpowiedzialności karnej. Obowiązujące regulacje ustawowe stanowią późną reminiscencję poglądów na sprawstwo oraz sprawcze postaci współdziałania, prezentowanych przed kilkudziesięciu laty, uwikłanych w intuicje sprawiedliwościowe oparte na pozbawionym podstaw przeświadczeniu o braku równorzędności sprawstwa i sprawczych postaci współdziałania oraz niesprawczych postaci współdziałania, stanowiącego podstawę dalekiego od racjonalności stałego poszerzania zakresu odpowiedzialności za sprawcze postaci współdziałania kosztem postaci niesprawczych, skutkującego daleko idącą dekompozycją systemu prawa karnego w tym obszarze. To sprawia, iż wykładnia aktualnie obowiązujących przepisów dotyczących współdziałania w popełnieniu przestępstwa indywidualnego pozbawiona jest jasnych wskazówek co do wykorzystywanego przez ustawodawcę modelu oraz przyjmowanych założeń kryminalnopolitycznych ${ }^{37}$. Ujmując rzecz życzliwie, wskazać trzeba, że daleka jest także od technicznolegislacyjnej doskonałości. W tym stanie rzeczy, w zależności od przyjmowanych przez poszczególnych interpretatorów założeń, wykorzystywanej teorii wykładni, wreszcie - stosunku do uzupełniającej analizy dogmatyczne metody analizy normatywnej oraz sposobu rekonstrukcji zawartości treściowej i funkcji norm -

37 Ta wada związana jest z niedostatecznym przemyśleniem oraz brakiem teoretycznego opracowania podstaw odpowiedzialności za sprawcze współdziałanie ekstraneusa w popełnieniu przestępstwa indywidualnego. $\mathrm{W}$ tym obszarze mamy do czynienia z podobnie nieuzasadnionym podejściem do zmian legislacyjnych, jak w obszarze radykalnie zmodyfikowanych i teoretycznie oraz dogmatycznie całkowicie nieprzemyślanych zmian w zakresie kary łącznej. 
sankcjonowanej oraz sankcjonującej ${ }^{38}$, w piśmiennictwie prezentowane są różniące się wyniki czynności interpretacyjnych, prowadzące w stosunkowo szerokim zakresie do odmiennych konsekwencji. Ten stan teoretycznego, dogmatycznego i kryminalnopolitycznego niedookreślenia podstaw zakresu i modelu ustawowego rozstrzygania kwestii odpowiedzialności karnej za współdziałanie w popełnieniu przestępstwa indywidualnego sprawia, że aktualnie, podobnie jak ponad 70 lat temu, w doktrynie i orzecznictwie prezentowane są różnorodne, częstokroć wzajemnie przeciwstawne poglądy, których trafności nie sposób ocenić, odwołując się do treści obowiązujących przepisów.

Próbując przedstawić opis aktualnych ustawowych rozwiązań w kontekście teoretycznych modeli oraz kryminalnopolitycznych zapatrywań w zakresie podstaw odpowiedzialności karnej ekstraneusa za sprawcze postaci współdziałania w popełnieniu przestępstwa indywidualnego, uzasadnione wydaje się przedstawienie kontekstu związanego z podstawami odpowiedzialności ekstraneusa za niesprawcze postaci współdziałania w popełnieniu przestępstwa indywidualnego. Takie podejście uzasadniać można w szczególności dwiema przesłankami. Po pierwsze, co starano się już zasygnalizować, teoretyczne podstawy oraz kryminalnopolityczne konsekwencje sposobu ustawowego rozwiązania podstaw odpowiedzialności za niesprawcze współdziałanie ekstraneusa w popełnieniu przestępstwa indywidualnego zostały w polskim piśmiennictwie stosunkowo dobrze opisane. Po wtóre - model rozwiązania kwestii podstaw odpowiedzialności karnej ekstraneusa za niesprawcze postaci współdziałania w popełnieniu przestępstwa indywidualnego wyznacza kontekst oraz stanowi kontrapunkt w rozważaniach nad sposobem ujęcia podstaw odpowiedzialności karnej ekstraneusa za sprawcze współdziałanie $\mathrm{w}$ popełnieniu przestępstwa indywidualnego, albowiem $\mathrm{z}$ teoretycznego punktu widzenia można, poszukując odpowiedzi na pytanie o sposób uregulowania podstaw odpowiedzialności za sprawcze współdziałanie ekstraneusa w popełnieniu przestępstwa indywidualnego, albo przyjąć założenie oparcia stosownej regulacji w tym zakresie na tym samym modelu, jaki wykorzystano przy regulacji podstaw odpowiedzialności ekstraneusa za niesprawcze postaci współdziałania w popełnieniu przestępstwa indywidualnego, albo też uznać, iż — np. ze względów teoretycznych, kryminalnopolitycznych lub dogmatycznych — problem współdziałania ekstraneusa za sprawcze współdziałanie w popełnieniu przestępstwa indywidualnego powinien opierać się na odmiennym od wykorzystanego w odniesieniu do niesprawczych postaci współdziałania modelu.

Odwołując się do obszernych analiz dotyczących problematyki podstaw odpowiedzialności karnej za niesprawcze postaci współdziałania przedstawionych

38 W zakresie podstaw odpowiedzialności karnej za przestępne współdziałanie co do znacznie przyjmowanego sposobu rekonstrukcji norm sankcjonowanej i sankcjonującej z przepisów prawa karnego oraz wynikających z określonych koncepcji normatywnych konsekwencji zob. m.in. P. Kardas, Teoretyczne podstawy..., s. 534 n.; Ł. Pohl, Struktura..., s. 171 n. 
w polskim piśmiennictwie w ciągu ostatnich dwudziestu lat, można stwierdzić, że kwestia podstaw odpowiedzialności za niesprawcze postaci współdziałania w odniesieniu do zagadnienia ustawowej charakterystyki podmiotu odpowiedzialności karnej została w polskim systemie prawa karnego rozwiązana na podstawie pierwszego z zarysowanych modeli teoretycznych, sprowadzającego się do autonomicznej charakterystyki podmiotu odpowiedzialności karnej w przypadku niesprawczych postaci współdziałania w ogólnym przepisie określającym podstawy odpowiedzialności karnej za te odmiany, skutkującej tym, iż w każdym przypadku — zarówno w powiązaniu z przestępstwem powszechnym, jak i w powiązaniu z przestępstwem indywidualnym - niesprawcze postaci współdziałania mają postać odrębnych typów czynu zabronionego - zawsze o powszechnej, w żaden sposób niezawężonej charakterystyce podmiotu odpowiedzialności karnej. Spoglądając na regulację podstaw odpowiedzialności za współdziałanie $\mathrm{w}$ popełnieniu przestępstwa indywidualnego z uwzględnieniem aktualnego stanu analiz teoretycznych i dogmatycznych, łatwo dostrzec, że wedle powszechnie akceptowanego $\mathrm{w}$ piśmiennictwie i orzecznictwie stanowiska niesprawcze postaci współdziałania oparte są na koncepcji ustawowego ujęcia podżegania i pomocnictwa jako odrębnych typów czynu zabronionego o własnych, różniących się od określonych dla sprawstwa i sprawczych postaci współdziałania, znamionach. Znamiona podżegania i pomocnictwa do każdego typu przestępstwa określane są łącznie w przepisie art. $18 \S 2$ lub art. 18 § k.k. oraz przepisie części szczególnej lub przepisie pozakodeksowym, charakteryzującym w formie sprawstwa pojedynczego (bezpośredniego) poszczególne odmiany przestępstw ${ }^{39}$. Powszechnie przyjmuje się, że znamiona typu podżegania oraz znamiona typu pomocnictwa zasadniczo opisane są w przepisach art. $18 \S 2 \mathrm{i}$ art. $18 \S 3$ k.k., traktowanych jako tzw. przepisy zrębowe, uadekwatniane przez przepisy określające poszczególne typy przestępstw w formie sprawstwa pojedynczego (bezpośredniego). Z uwagi na sposób ustawowego ujęcia znamion typu podżegania i pomocnictwa $\mathrm{w}$ oparciu o wykorzystanie techniki rozczłonkowania i kondensacji tekstu prawnego, przepisy art. $18 \S 2$ i art. $18 \S 3$ k.k. umożliwiają odczytanie znamion typu podżegania lub typu pomocnictwa w powiązaniu z każdym przepisem typizującym przestępstwo rodzajowe w formie sprawstwa pojedynczego (bezpośredniego), niezależnie od tego, czy przepis typizujący określa przestępstwo powszechne, czy też przestępstwo indywidualne, właściwe lub niewłaściwe oraz niezależnie od tego, czy w przypadku przestępstw indywidualnych niewłaściwych chodzi o ukształtowanie typu zmodyfikowanego w postaci kwalifikowanej czy też uprzywilejowanej. $\mathrm{Z}$ perspektywy charakterystyki podmiotu typy podżegania i pomocnictwa ujęte

39 Szerzej co do teoretycznych, metodologicznych i dogmatycznych podstaw tej koncepcji zob. P. Kardas, Teoretyczne podstawy..., s. 440 n. oraz powołana tam literatura przedmiotu i orzecznictwo. Zob. też A. Liszewska, Współdziałanie..., s. 34 n. 
są w każdym przypadku jako tzw. typy powszechne ${ }^{40}$, albowiem charakterystyka podmiotu odpowiedzialności karnej jest $\mathrm{w}$ tych przypadkach określona $\mathrm{w}$ zrębowych przepisach art. $18 \S 2$ i art. $18 \S 3$ k.k., co sprawia, iż uadekwatnienie treściowe poprzez wykorzystanie przepisów typizujących przestępstwa rodzajowe w formie sprawstwa pojedynczego (bezpośredniego) nie modyfikuje powszechnej charakterystyki podmiotu podżegania i pomocnictwa ${ }^{41}$. Wykorzystana do określenia podstaw odpowiedzialności za podżeganie i pomocnictwo przez polskiego ustawodawcę technika legislacyjna, stanowiącą konsekwencję teoretycznego ujęcia podstaw odpowiedzialności za te odmiany współdziałania w koncepcji wypracowanej przez J. Makarewicza, przesądza, że podżeganie i pomocnictwo do przestępstwa indywidualnego, właściwego i niewłaściwego jest w każdym przypadku ukształtowane jako typ o powszechnej charakterystyce podmiotu odpowiedzialności karnej ${ }^{42}$. Ukształtowanie znamion strony podmiotowej podżegania i pomocnictwa jako typów umyślnych przesądza, że w wypadku podżegania lub pomocnictwa do przestępstwa indywidualnego konieczne jest skierowanie czynności nakłaniania lub ułatwiania na osobę bezpośredniego wykonawcy, mającego cechy wymagane od sprawcy przestępstwa indywidualnego oraz świadomość istnienia tej cechy po stronie podżegacza i pomocnika ${ }^{43}$. Przy czym z uwagi na konstrukcyjne właściwości typów podżegania i pomocnictwa odpowiedzialność karna za te postaci współdziałania do przestępstwa indywidualnego w każdym przypadku wymaga ukierunkowania zachowania nakłaniającego lub ułatwiającego na osobę mającą cechy wymagane od sprawcy przestępstwa indywidualnego, niezależnie od tego, czy nakłaniający lub ułatwiający także ma takie cechy, a więc z perspektywy przestępstwa indywidualnego, określonego w formie sprawstwa pojedynczego (bezpośredniego), jest intraneusem, czy też nakłaniający i ułatwiający cech takich nie ma i z perspektywy przestępstwa indywidualnego, określonego w formie sprawstwa pojedynczego (bezpośredniego), jest ekstraneusem ${ }^{44}$. Pozwala to konstatować, że przesłanki odpowiedzialności za podżeganie i po-

40 Stanowisko to jest aktualnie powszechnie aprobowane w doktrynie prawa karnego. Zob. w szczególności P. Kardas, Teoretyczne podstawy..., s. 440 n.; A. Liszewska, Odpowiedzialność..., s. 17. Por. też R. Dębski, op. cit., s. 17-18; A. Zoll, Podstawy teoretyczne..., s. 39; Ł. Pohl, Wykład..., s. 189-190; J. Giezek [w:] J. Giezek, N. Kłączyńska, G. Łabuda, op. cit., s. 185-186.

41 Szerzej w tej kwestii zob. P. Kardas, Teoretyczne podstawy..., s. 456 n.

42 Stanowisko to zostało zaakceptowane w piśmiennictwie, w którym wskazuje się, że ,przestępstwo podżegania i pomocnictwa mają zawsze charakter ogólnosprawczy" — A. Liszewska, $O d$ powiedzialność..., s. 17. Por. też R. Dębski, op. cit., s. 17-18; A. Zoll, Podstawy teoretyczne..., s. 39.

${ }^{43}$ Zob. w tym zakresie interesujące uwagi m.in. J. Giezka [w:] J. Giezek, N. Kłączyńska, G. Łabuda, op. cit., s. 185-186; Ł. Pohla, Struktura..., s. 171 n.

44 Trafnie i zarazem lakonicznie stwierdza A. Liszewska, że ,indywidualne cechy podżegacza i pomocnika nie mają — w kontekście ogólnosprawczego charakteru popełnianych przez nich czynów zabronionych — żadnego znaczenia" — eadem, Odpowiedzialność..., s. 19. Zob. też rozważania J. Giezka [w:] J. Giezek, N. Kłączyńska, G. Łabuda, op. cit., s. 185-186. Zob. też rozważania A. Barczak-Oplustil, ,W związu z petnieniem funkcji publicznych” jako znamię dookreślające 
mocnictwo określone zostały dla każdego przypadku podżegania i pomocnictwa do przestępstwa indywidualnego w sposób identyczny, jak wskazano to w treści art. 19 § 2 k.k. z 1969 r. oraz w art. $21 \S 2$ k.k. z 1997 r. Zarazem przesłanki te wynikają z treści art. $18 \S 2$ i art. $18 \S 3$ k.k. i nie wymagają szczególnej regulacji, zawartej niegdyś w art. 19 § 2 k.k. z 1969 r., aktualnie zaś w art. 21 § 2 k.k. Oznacza to, że odpowiedzialność za podżeganie i pomocnictwo do przestępstwa indywidualnego jest w polskim systemie prawnym możliwa ze względu na sposób określenia znamion typów podżegania i pomocnictwa oraz wynika z ogólnych właściwości tych odrębnych typów czynu zabronionego ${ }^{45}$. Stąd też w piśmiennictwie podkreśla się, że art. 21 § 2 k.k. z 1997 r. (a także art. 19 § 2 k.k. z 1969 r. w okresie obowiązywania tego kodeksu karnego) stanowiły w perspektywie podstawy odpowiedzialności za podżeganie i pomocnictwo do przestępstwa indywidualnego ustawowe suprefluum, wprowadzone do ustawy w celu rozstrzygnięcia wątpliwości wynikających z błędnej wykładni przepisów statuujących podstawy odpowiedzialności za podżeganie i pomocnictwo w polskim systemie prawa karnego oraz potwierdzających jedynie to, co wynika z konstrukcji znamion podżegania i pomocnictwa ${ }^{46}$. Czasami, opierając się na przedstawionym stanowisku, wskazuje się na całkowitą zbędność art. $21 \S 2$ k.k. w odniesieniu do podżegania i pomocnictwa do przestępstw indywidualnych ${ }^{47}$.

Trzeba zarazem podkreślić, że w odniesieniu do normatywnej zawartości oraz funkcji art. $21 \S 2$ k.k. w zakresie odpowiedzialności za podżeganie i pomocnictwo do przestępstwa indywidualnego w piśmiennictwie i orzecznictwie przyjmuje się, iż przepis ten odgrywa konstytutywną rolę $\mathrm{w}$ zakresie modyfikacji podstaw odpowiedzialności za podżeganie i pomocnictwo do przestępstwa indywidualnego niewłaściwego typu uprzywilejowanego, wyłączając w tym zakresie zasady ogólne, wynikające $\mathrm{z}$ właściwości konstrukcyjnych typów podżegania i pomocnictwa, oraz stanowiąc podstawę do pociągania w takim przypadku do odpowiedzialności za podżeganie i pomocnictwo do typu podstawowego o powszechnej charakterystyce podmiotu odpowiedzialności karnej ${ }^{48}$. Jakkolwiek taka wykładnia jest

czynność sprawczą tzw. korupcji urzędniczej-zarys wybranych problemów, „Czasopismo Prawa Karnego i Nauk Penalnych" 2009, z. 3, s. 75-96.

45 Wypada w tym miejscu powtórzyć przedstawione 16 lat temu stanowisko, że „skomplikowany problem podżegania do przestępstw indywidualnych jawi się w świetle przedstawionych wyżej wywodów jako rozwiązywalny bez konieczności odwoływania się do specjalnego przepisu ustawy" - P. Kardas, Teoretyczne podstawy..., s. 591, 635. Tak też aprobująco Ł. Pohl, Wyktad..., s. 187 n.; A. Liszewska, Odpowiedzialność..., s. 13 n.; R. Dębski, op. cit., s. 15 n.

46 Zob. szerzej w tej kwestii A. Liszewska, Odpowiedzialność..., s. 19 n.; P. Kardas [w:] G. Bogdan et al., op. cit., s. 407-408; J. Giezek, Kodeks karny. Część ogólna, s. 121-123.

47 Tak w szczególności Ł. Pohl, Wykład..., s. 187 n.; Ł. Pilarczyk, Analiza..., s. 94.

48 Zob. szerzej w tej kwestii P. Kardas [w:] G. Bogdan et al., op. cit., s. 407-408; J. Giezek, Kodeks karny..., s. 121-123. Por. też A. Liszewska, Odpowiedzialność..., s. 5 n. Por. też stanowisko J. Giezka [w:] J. Giezek, N. Kłączyńska, G. Łabuda, op. cit., s. 185-186. Warto jednak zwrócić uwagę na wątpliwości i zastrzeżenia formułowane przez J. Giezka [w:] ibidem, s. 185-186. 
powszechnie aprobowana $\mathrm{w}$ piśmiennictwie i przyjmowana $\mathrm{w}$ orzecznictwie, to trzeba uczciwie przyznać, że konstrukcyjnie i technicznolegislacyjnie w tym akurat obszarze przepis art. $21 \S 2 \mathrm{k} . \mathrm{k}$. nie został ukształtowany poprawnie. Jeśli ustawodawca zamierzał wyłączyć zasady ogólne związane z określeniem w przepisach art. $18 \S 2$ i 3 k.k. podmiotu odpowiedzialności karnej w przypadku typu podżegania i pomocnictwa jako podmiotu powszechnego w odniesieniu do podżegania i pomocnictwa do przestępstwa indywidualnego niewłaściwego typu uprzywilejowanego, kierując się np. względami kryminalnopolitycznymi, to należało kwestię tę w sposób jednoznaczny uregulować, wprowadzając do kodeksu karnego przepis statuujący wyjątek od ogólnej zasady. Pobieżne wejrzenie na treść art. 21 § 2 k.k. przekonuje, że takich regulacji w tym przepisie, z powodów oczywistych, nie ma. To zaś sprawia, iż prezentowana większościowa wykładnia kwestii podstaw odpowiedzialności karnej ekstraneusa za podżeganie i pomocnictwo do przestępstwa indywidualnego niewłaściwego typu uprzywilejowanego, jakkolwiek ma dobre uzasadnienie kryminalnopolityczne, nie jest jednak oparta na właściwie ujętej treści art. 21 § 2 k.k. Z tych też względów może być kwestionowana.

Przedstawiona tu rekonstrukcja ustawowego ujęcia podstaw odpowiedzialności za podżeganie i pomocnictwa pozwala konstatować, że ustawodawca skorzystał z modelu opartego na ujęciu typu podżegania i pomocnictwa do przestępstwa indywidualnego jako odrębnego typu czynu zabronionego o powszechnej charakterystyce podmiotu odpowiedzialności karnej z uzupełnieniem odwołującym się do regulacji szczególnej wyłączającej przypisanie odpowiedzialności za podżeganie i pomocnictwo do przestępstwa indywidualnego niewłaściwego typu uprzywilejowanego, przewidując $\mathrm{w}$ takim wypadku odpowiedzialność podżegacza i pomocnika za podżeganie i pomocnictwo do typu podstawowego ${ }^{49}$. Zasada ta w polskim systemie prawa odnosi się do wszystkich przypadków podżegania i pomocnictwa do przestępstwa indywidualnego niewłaściwego typu uprzywilejowanego, a więc zarówno tych, gdy podżegacz i pomocnik nie ma cech wymaganych od sprawcy przestępstwa indywidualnego, jest zatem z punktu widzenia przestępstwa indywidualnego niewłaściwego typu uprzywilejowanego ekstraneusem, jak i tych sytuacji, gdy podżegacz i pomocnik mają cechy wymagane od sprawcy przestępstwa indywidualnego, jest zatem z perspektywy przestępstwa indywidualnego niewłaściwego typu uprzywilejowanego intraneusem ${ }^{50}$. W odniesieniu do obu opisanych układów odpowiedzialność za podżeganie i pomocnictwo do przestępstwa typu podstawowego wynika z regulacji szczególnej zawartej $\mathrm{w}$ art. $21 \S 2$ k.k. w zw. z art. $21 \S 1$ k.k. ${ }^{51}$ Trzeba jednak podkreślić, że w zakresie odpowiedzialności za podżeganie i pomocnictwo do przestępstwa in-

49 Zob. jednak interesujące rozważania J. Giezka [w:] J. Giezek, N. Kłączyńska, G. Łabuda, op. cit., s. 185-186.

50 Por. ibidem.

51 P. Kardas [w:] G. Bogdan et al., s. 407-408; J. Giezek, Kodeks karny..., s. 121-123. 
dywidualnego niewłaściwego typu uprzywilejowanego przepis art. $21 \S 2$ k.k. nie został ukształtowany w sposób prawidłowy ${ }^{52}$. Zarazem wadliwość konstrukcyjna art. $21 \S 2$ k.k. w omawianym zakresie, jakkolwiek kłopotliwa i niezbyt dobrze świadcząca o projektodawcach tego rozwiązania, w kontekście określonych założeń kryminalnopolitycznych umożliwia wykładnię służącą do korekty ogólnej zasady odpowiedzialności za podżeganie i pomocnictwo do każdego przestępstwa indywidualnego, wynikającej z właściwości konstrukcyjnych tych postaci współdziałania, opartej na wyjątkowym przepisie, jakim jest właśnie art. $21 \S 2$ k.k. ${ }^{53}$

$\mathrm{W}$ piśmiennictwie prezentowane jest także odmienne ujęcie oparte na twierdzeniu, że podżeganie i pomocnictwo do każdego przestępstwa oparte jest na ujęciu znamion odrębnego typu podżegania i pomocnictwa o powszechnej charakterystyce podmiotu odpowiedzialności karnej, art. $21 \S 2$ k.k. zaś nie modyfikuje ogólnych zasad odpowiedzialności za podżeganie i pomocnictwo do przestępstwa indywidualnego w żadnym zakresie, co sprawia, iż odnoszą się one także do podżegania i pomocnictwa do przestępstwa indywidualnego niewłaściwego typu uprzywilejowanego ${ }^{54}$. Stanowisko to bywa kwestionowane ze względu na

52 Trafnie podkreśla A. Liszewska, że ,zgadzając się z koniecznością odrębnego uregulowania kwestii podżegania i pomocnictwa do przestępstw indywidualnych niewłaściwych typu uprzywilejowanego, należy zauważyć, że art. $21 \S 2$ k.k. nie został w tym zakresie prawidłowo skonstruowany. Poprawniej byłoby, gdyby odpowiedni przepis przewidywał wyjątek od wynikającej z konstrukcji znamion podżegania i pomocnictwa zasady mówiącej, że niezależnie od charakteru czynu zabronionego, do którego podżegacz nakłania, a pomocnik pomaga, ponosi on odpowiedzialność. Wyjątek ten dotyczyłby właśnie przestępstw indywidualnych niewłaściwych. Chodzi bowiem o to, że według ogólnej zasady nakłaniający matkę znajdującą się w okresie porodu i pod wpływem jego przebiegu do zabicia dziecka, powinien odpowiadać za podżeganie do dzieciobójstwa (art. 18 § 2 k.k. w zw. z art. 149 k.k.). Aby mógł on odpowiadać za podżeganie do zabójstwa, odpowiedni przepis k.k. powinien przewidywać wyjątek dotyczący tylko wypadków podżegania i pomocnictwa do takich czynów zabronionych, przy których szczególna cecha sprawcy wpływa na niższą karalność" - A. Liszewska, Odpowiedzialnośćc..., s. 19. Zob. też uwagi J. Giezka [w:] J. Giezek, N. Kłączyńska, G. Łabuda, op. cit., s. 185-186.

53 Odmiennie zagadnienie to, także w perspektywie kryminalnopolitycznej, ujmuje Ł. Pohl, O prawno-karnych ocenach realizowanego w okresie porodu i pod wptywem jego przebiegu niewykonawczego współdziałania przestępnego matki z osobą dopuszczająca się lub mogąca się dopuścić zabójstwa jej dziecka w tym okresie, [w:] Problemy wymiaru sprawiedliwości karnej. Księga jubileuszowa Profesora Jana Skupińskiego, red. J. Jakubowska-Hara et al., Warszawa 2013, s. 291 n. Zob. też rozważania Ł. Pilarczyka, Analiza..., s. 90 n.; oraz J. Giezka [w:] J. Giezek, N. Kłączyńska, G. Łabuda, op. cit., s. 185-186.

54 Ł. Pohl, Wykład..., s. 189-190. Por. też stanowisko J. Giezka, podkreślającego, że „podręcznikowy już niemal przykład może stanowić matka, która — znajdując się w okresie porodu oraz pod wpływem jego przebiegu — nakłania odbierającego poród lekarza, aby zabił jej rodzące się właśnie dziecko. Jeśliby w takim przypadku wobec matki zastosowanie miał znaleźć art. $21 \S 1$ k.k., a w rezultacie przypisano by jej podżeganie do przestępstwa indywidualnego kwalifikowanego z art. 149 k.k. (czyli przestępstwa indywidualnego niewłaściwego, co w takim stanie faktycznym wydaje się najwłaściwsze), to przecież tylko dzięki temu, że okazała się ona podżegającym intraneusem" - J. Giezek [w:] J. Giezek, N. Kłączyńska, G. Łabuda, op. cit., s. 185-186. 
normatywną zawartość i znaczenie regulacji zawartej w przepisie art. $21 \S 2$ k.k. oraz z powodów kryminalnopolitycznych ${ }^{55}$ i aksjologicznych ${ }^{56}$.

Różnica między przedstawionymi tu ujęciami podstaw odpowiedzialności za podżeganie i pomocnictwo do przestępstwa indywidualnego sprowadza się wyłącznie do mocno skomplikowanej w perspektywie kryminalnopolitycznej oraz głęboko uwikłanej aksjologicznie ${ }^{57}$ kwestii odpowiedzialności za podżeganie i pomocnictwo do przestępstwa indywidualnego niewłaściwego typu uprzywilejowanego, a także związanej z kontrowersjami odnośnie do podstaw odpowiedzialności karnej za podżeganie i pomocnictwo w takich wypadkach relacji między przepisami art. $18 \S 2$ i art. $18 \S 3$ k.k. a przepisem art. $21 \S 2$ k.k.

W pierwszym ujęciu, wskazując, iż podstawy odpowiedzialności za podżeganie i pomocnictwo do przestępstw indywidualnych wynikają z konstrukcyjnych właściwości tych odrębnych typów czynu zabronionego, a więc przede wszystkim z treści art. $18 \S 2 \mathrm{i}$ art. $18 \S 3$ k.k., przyjmuje się jednocześnie, że w zakresie przestępstw indywidualnych niewłaściwych typu uprzywilejowanego przepis art. 21 $\S 2$ k.k. ma charakter szczególny, określając wyjątek od zasady ogólnej wynikającej z ogólnosprawczego charakteru typów podżegania i pomocnictwa. W tym ujęciu podstawy odpowiedzialności za podżeganie i pomocnictwo do przestępstw indywidualnych niewłaściwych typu uprzywilejowanego określają łącznie art. 18 $\S 2$ i art. $18 \S 3$ k.k. oraz art. $21 \S 2$ k.k. w zw. z art. $21 \S 1$ k.k., przewidujące wyjątek od ogólnej reguły wskazanej w art. 18 § 2 iart. 18 3 k.k. Tym samym w zakresie podstaw odpowiedzialności za podżeganie i pomocnictwo do przestępstwa indywidualnego niewłaściwego typu uprzywilejowanego w tej koncepcji art. 21 $\S 2 \mathrm{w}$ zw. z art. $21 \S 1$ k.k. traktowany jest jako przepis uzupełniający art. $18 \S 2$ k.k. i art. $18 \S 3$ k.k. w zakresie określenia podstaw odpowiedzialności za podżeganie i pomocnictwo. Artykuł $21 \S 2$ k.k. ma w tym ujęciu charakter przepisu szczególnego, modyfikującego w zakresie podstaw odpowiedzialności za podżeganie i pomocnictwo do przestępstwa indywidualnego typu uprzywilejowanego podstawy i w konsekwencji — zakres odpowiedzialności karnej. W podejściu alternatywnym przyjmuje się, że podstawy odpowiedzialności karnej za podżeganie i pomocnictwo we wszystkich przypadkach określają samoistnie art. $18 \S 2$ i art. 18 $\S 3$ k.k., przepis art. $21 \S 2$ k.k. zaś nie odnosi się do podżegania i pomocnictwa, $\mathrm{i}$ jest $\mathrm{w}$ tym zakresie przepisem pustym ${ }^{58}$.

Z perspektywy modelowej pierwsze z przedstawionych stanowisk odwołuje się do wykorzystania w procesie ustawowej regulacji podstaw odpowiedzialności za podżeganie i pomocnictwo koncepcji skutkującej nadaniem podżeganiu i pomocnictwu w każdym przypadku charakteru przestępstw ogólnosprawczych,

\footnotetext{
55 A. Liszewska, Odpowiedzialność..., s. 19.

56 Por. stanowisko J. Giezka [w:] J. Giezek, N. Kłączyńska, G. Łabuda, op. cit., s. 185-186.

57 Zob. w tej kwestii ibidem.

58 Por. Ł. Pilarczyk, Analiza..., s. 92.
} 
a więc w przypadku podżegania i pomocnictwa do przestępstw indywidualnych prowadzącej do przekształcenia typu o zawężonym kręgu podmiotów sprawczych w formie sprawstwa pojedynczego (bezpośredniego) w powszechny (ogólnosprawczy) typ podżegania i pomocnictwa, z tym uzupełnieniem, że w odniesieniu do podżegania i pomocnictwa do przestępstw indywidualnych niewłaściwych typu uprzywilejowanego wykorzystującego także w części model regulacji szczególnej, modyfikujący ogólne zasady wynikające z wykorzystania modelu opartego na przekształceniu podżegania i pomocnictwa do przestępstwa indywidualnego w przestępstwa powszechne.

Drugie z przedstawionych stanowisk opiera się konsekwentnie na założeniu wykorzystania w procesie ustawowej regulacji podstaw odpowiedzialności za podżeganie i pomocnictwo koncepcji skutkującej nadaniem podżeganiu i pomocnictwu w każdym przypadku charakteru przestępstw ogólnosprawczych, a więc w przypadku podżegania i pomocnictwa do przestępstw indywidualnych prowadzącej do przekształcenia typu o zawężonym kręgu podmiotów sprawczych w formie sprawstwa pojedynczego (bezpośredniego) w powszechny (ogólnosprawczy) typ podżegania i pomocnictwa bez wprowadzenia jakichkolwiek wyjątków w odniesieniu do podżegania i pomocnictwa do przestępstw indywidualnych niewłaściwych typu uprzywilejowanego.

$\mathrm{W}$ odniesieniu do sprawczych postaci współdziałania w popełnieniu przestępstwa indywidualnego zakres i skala kontrowersji dotyczących podstaw odpowiedzialności karnej, jej konsekwencji oraz przyjmowanych przez ustawodawcę założeń kryminalnopolitycznych jest zdecydowanie większa niż w wypadku niesprawczego współdziałania w popełnieniu przestępstwa indywidualnego.

Wedle dominującego w doktrynie i piśmiennictwie ujęcia zasadnicze znaczenie w zakresie odpowiedzialności za sprawcze postaci współdziałania w popełnieniu przestępstwa indywidualnego ma wprowadzony do polskiego systemu prawa karnego przez kodeks karny z 1997 r. przepis art. $21 \S 2$ k.k. Powszechnie przyjmuje się, że ma on znaczenie konstytutywne, albowiem określa podstawy odpowiedzialności ekstraneusa za sprawcze postaci współdziałania, która nie byłaby możliwa bez wprowadzenia do ustawy karnej szczególnej regulacji. Przyjmuje się zatem, że przepis ogólny, dotyczący sprawczych postaci współdziałania, nie odnosi się do charakterystyki podmiotu odpowiedzialności karnej, który zawsze i w sposób zupełny charakteryzowany jest w typie czynu zabronionego, określonym $w$ formie sprawstwa pojedynczego (bezpośredniego). W tym zakresie przyjmuje się zatem, przeciwne do wykorzystywanego w odniesieniu do podżegania i pomocnictwa, założenie, wedle którego przepis art. $18 \S 1$ zdanie drugie, trzecie i czwarte służy wyłącznie do modyfikacji znamion strony przedmiotowej, w szczególności zaś znamienia czynnościowego, odmiennie ukształtowanego w wypadku sprawstwa pojedynczego bezpośredniego, odmiennie zaś w wypadku sprawczych postaci współdziałania. Zarazem zakłada się, że art. 18 § k.k. zdanie 
drugie, trzecie i czwarte nie modyfikuje w żadnym zakresie znamion charakteryzujących podmiot odpowiedzialności karnej, zawartych w typie określającym znamiona sprawstwa pojedynczego (bezpośredniego). Jakkolwiek stanowisko to jest powszechnie prezentowane w polskim piśmiennictwie karnistycznym, to trudno wskazać zestaw argumentów będących jego teoretycznymi, dogmatycznymi i kryminalnopolitycznymi uzasadnieniami.

Rekonstruując prezentowane w tym zakresie poglądy, można wskazać, że zasadniczo podkreśla się, iż taki sposób wykładni przepisów określających podstawy odpowiedzialności za sprawcze postaci współdziałania wynika z istoty sprawstwa, powiązanego w każdej postaci z realizacją typu czynu zabronionego, określonego w formie sprawstwa pojedynczego (bezpośredniego) w przepisach części szczególnej lub przepisach pozakodeksowych w sposób określony w art. $18 \S 1$ k.k. zdanie drugie, trzecie i czwarte dla poszczególnych odmian sprawczego współdziałania. Wskazuje się ponadto, że w polskim systemie prawa karnego — jakkolwiek każda $\mathrm{z}$ odmian sprawstwa, tj. sprawstwo pojedyncze, współsprawstwo, sprawstwo kierownicze i sprawstwo polecające, stanowi odrębny typ czynu zabronionego i ma własne znamiona - sprawstwo we wszystkich postaciach charakteryzuje się wspólnymi cechami, w szczególności tym, że zawsze sprowadza się do określonej przez ustawodawcę formy „wykonania” czynu zabronionego. To sprawia, że właśnie wykonanie czynu zabronionego na jeden z przewidzianych $\mathrm{w}$ art. $18 \S 1$ k.k. sposobów stanowi istotę sprawstwa. Podkreśla się także, że wszystkie uregulowane w art. $18 \S 1$ k.k. odmiany sprawczego współdziałania traktowane są jako sprawstwo, regulacja zaś dotycząca sprawczych postaci współdziałania określa jedynie swoiste, techniczne sposoby realizacji znamion czynu zabronionego określonego w części szczególnej lub ustawach pozakodeksowych zmodyfikowanych przez elementy zaczerpnięte $\mathrm{z}$ art. 18 § 1 k.k. Jakkolwiek wykorzystanie przepisu art. $18 \S 1$ k.k. zdanie drugie, trzecie i czwarte w procesie rekonstrukcji znamion czynu zabronionego w postaci współsprawstwa, sprawstwa kierowniczego oraz sprawstwa polecającego prowadzi do odczytania różniących się od określonych dla sprawstwa pojedynczego znamion, a w konsekwencji odkodowania innych typów czynu zabronionego ${ }^{59}$, to jednak wedle powszechnego przekonania znamiona każdej z postaci sprawstwa, a więc sprawstwa pojedynczego, współsprawstwa, sprawstwa kierowniczego oraz sprawstwa polecającego określają pojedyncze, realizowane przez jedną osobę (sprawstwo pojedyncze) lub realizowane przez co najmniej dwie osoby (współsprawstwo, sprawstwo kierownicze oraz sprawstwo polecające) zachowania prowadzące do wypełnienia znamion przewidzianych

$59 \mathrm{Na}$ taką konsekwencję uregulowania zawartego w art. 18 § 1 k.k. wskazywałem wielokrotnie. Zob. w tej kwestii w szczególności P. Kardas, Teoretyczne podstawy..., idem, Istota wspótsprawstwa w polskim prawie karnym. Uwagi na marginesie trzech orzeczeń Sądu Najwyższego, „Prokuratura i Prawo”2005, nr 12, s. 7-37; idem, Zbieg przepisów ustawy a sprawcze i niesprawcze postaci współdziałania, „Prokuratura i Prawo” 2005, nr 7-8, s. 87-124. 
w art. $18 \S 1$ k.k. oraz w przepisie części szczególnej lub przepisie pozakodeksowym w sposób określony w art. 18 § 1 k.k. Uzupełniając to twierdzenie o powszechnie akceptowaną zasadę równorzędności sprawczych postaci współdziałania i sprawstwa pojedynczego, należy wskazać, iż zasadniczo przyjmuje się, że funkcję modyfikującą przepis art. $18 \S 1$ k.k. w odniesieniu do sprawczych postaci współdziałania pełni jedynie w zakresie charakterystyki znamion czynnościowych $^{60}$. W odniesieniu do powyższego twierdzenia nie ma większego znaczenia to, czy w szczególności sprawstwo kierownicze i sprawstwo polecające uznaje się za konstrukcje oparte na zasadzie akcesoryjności ${ }^{61}$, czy też przyjmuje ich w pełni nieakcesoryjny status ${ }^{62}$. Zarazem $w$ polskim piśmiennictwie i orzecznictwie zdecydowanie przeważa stanowisko, zgodnie z którym przepis art. 18 § 1 k.k. nie modyfikuje w odniesieniu do sprawczych postaci współdziałania ustawowej charakterystyki podmiotu odpowiedzialności karnej. Innymi słowy — powszechnie przyjmuje się, od czasów obowiązywania kodeksu karnego z 1932 r., że zwiększenie zakresu odpowiedzialności za sprawstwo na sprawcze postaci współdziałania nie zmienia charakterystyki podmiotu przestępstwa indywidualnego w każdej z odmian, co oznacza, że dla odpowiedzialności za sprawstwo i sprawcze postaci współdziałania, gdyby oceniać ją wyłącznie w perspektywie treści normatywnej art. $18 \S 1$ k.k. (lub poprzednio art. 16 k.k. z 1969 r.), konieczne jest spełnienie przez współsprawcę, sprawcę kierowniczego lub sprawcę polecającego cech określonych przez znamiona zawartego w części szczególnej lub ustawach pozakodeksowych typu czynu zabronionego określającego przestępstwo o zawężonym kręgu podmiotów ${ }^{63}$. Przepis art. $18 \S 1$ k.k., wedle powszechnie akceptowanego stanowiska, nie modyfikuje zatem w odniesieniu do sprawczych postaci współdziałania znamion przewidzianej w przepisie części szczególnej lub przepisie pozakodeksowym charakterystyki podmiotu. Do pociągnięcia osoby niemającej cech wymaganych od sprawcy przestępstwa indywidualnego za współsprawstwo, sprawstwo kierownicze lub sprawstwo polecające konieczna jest szczególna regulacja ustawowa, bez której taka odpowiedzialność nie jest w ogóle możliwa.

$60 \mathrm{~W}$ pewnym sensie nawiązuje się także do stanowiska prezentowanego na gruncie kodeksu karnego z 1932 r., w którym brakowało przepisu ogólnego odnoszącego się do określenia podstaw odpowiedzialności karnej za współsprawstwo. Zob. w tym zakresie uwagi zamieszczone w przypisach nr 42 i nr 51.

61 Zob. szerzej P. Kardas, Teoretyczne podstawy..., s. 487 n.; A. Liszewska, Współdziałanie..., s. $10 \mathrm{n}$.

${ }^{62}$ Zob. w szczególności Ł. Pohl, Obiektywna istota sprawstwa w ujęciu polskiego kodeksu karnego (uwagi na marginesie lektury pracy P. Kardasa „Teoretyczne podstawy odpowiedzialności karnej za przestepne współdziałanie”), RPEiS 2004, nr 2, s. 282 n.; idem, Zawartość normatywna przepisu art. 18 \& 1 k.k., Prok. i Pr. 2006, nr 2; idem, Wyktad..., s. 172; Ł. Pilarczyk, Postulaty..., s. $96 \mathrm{n}$.

63 Zob. w tej kwestii A. Liszewska, Odpowiedzialność..., s. 19 n. 
Funkcję tę pełni art. $21 \S 2$ k.k., określając konstytutywne przesłanki odpowiedzialności współdziałającego sprawczo w popełnieniu przestępstwa indywidualnego ${ }^{64}$. To ujęcie oparte jest na modelu zachowania w odniesieniu do sprawczych postaci współdziałania charakteru przestępstwa określonego przez znamiona formy sprawstwa pojedynczego (bezpośredniego). Tym samym z punktu widzenia ustawowej charakterystyki podmiotu odpowiedzialności karnej sprawcze postaci współdziałania w popełnieniu przestępstwa indywidualnego, właściwego lub niewłaściwego zachowują status przestępstw indywidualnych, które co do zasady mogą popełnić jedynie współdziałający mający cechy wymagane od sprawcy. Kwestia ewentualnej odpowiedzialności ekstraneusa współdziałającego sprawczo w popełnieniu przestępstwa o zawężonym kręgu podmiotów wymaga szczególnej regulacji, opartej na fikcji prowadzącej do uznania na potrzeby odpowiedzialności karnej, w razie spełnienia wymienionych w ustawie przesłanek, że ekstraneus ma cechy wymagane odnośnie do sprawcy, a więc przyjęcia w takim wypadku fikcji prawnej umożliwiającej pociągnięcie ekstraneusa do odpowiedzialności za sprawcze współdziałanie w popełnieniu przestępstwa indywidualnego. W konsekwencji regulacja odnosząca się do tego typu przypadków, zawarta w art. $21 \S 2$ k.k., odnosi się wyłącznie do ekstraneusa, wymagając, by współdziałał z osobą mającą cechy wymagane od sprawcy przestępstwa indywidualnego oraz wiedział, iż współdziałająca osoba je ma.

W piśmiennictwie prezentowany jest także odmienny pogląd, zgodnie z którym w przypadku sprawczych postaci współdziałania w popełnieniu przestępstwa kwestia odpowiedzialności ekstraneusa uregulowana została na podstawie modelu przekształcenia przestępstwa, mającego charakter typu indywidualnego $\mathrm{w}$ formie sprawstwa pojedynczego (bezpośredniego), w przestępstwo o powszechnej charakterystyce podmiotu współdziałającego w wypadku tzw. niewykonawczych ${ }^{65}$ odmian sprawczego współdziałania, tj. sprawstwa kierowniczego oraz sprawstwa polecającego ${ }^{66}$, oraz podmiotu o charakterystyce indywidualnej w wypadku wy-

64 Zob. w tej kwestii ibidem.

65 Co do rozróżnienia na tzw. wykonawcze i niewykonawcze odmiany sprawczego współdziałania, przyjmowanych w tym zakresie kryteriów, zasadności tego podziału oraz wynikających z niego konsekwencji zob. w szczególności P. Kardas, Sprawstwo kierownicze i polecajace wykonawcze czy niewykonawcze postaci sprawstwa?, „Przegląd Sądowy” 2006, nr 5, s. 75-106; Ł. Pohl, Obiektywna..., s. 292 n.; idem, Zawartość...; R. Dębski, Jeszcze o tzw. sprawstwie niewykonawczym (kierowniczym i polecajacym) w kodeksie karnym z 1997 r., [w:] Przestępstwo — kara - polityka kryminalna. Problemy tworzenia i funkcjonowania prawa. Ksiega jubileuszowa z okazji 70. rocznicy urodzin Profesora Tomasza Kaczmarka, red. J. Giezek, Kraków 2006, s. 148 n.

${ }^{66}$ Konsekwentnym zwolennikiem tej koncepcji jest Ł. Pohl, przyjmujący, że „współdziałający więc, którym co do zasady może być każdy człowiek (wyjątkiem jest w tym zakresie bowiem podmiot pomocnictwa przez zaniechanie) może swoim zachowaniem się zrealizować znamiona każdej niewykonawczej formy współdziałania przestępnego indywidualnego czynu zabronionego pod groźbą kary. Wynika to z faktu, że normy sankcjonowane, zakazujące pod groźbą kary dopuszczenia się owych form, zaadresowane są do każdego człowieka. Stąd na gruncie indywidualnego 
konawczych postaci sprawstwa, tj. sprawstwa pojedynczego (bezpośredniego) oraz współsprawstwa ${ }^{67}$. Łatwo dostrzec, że to podejście opiera się na założeniu identyczności konstrukcyjnej oraz technicznolegislacyjnej niesprawczych postaci współdziałania oraz sprawczych niewykonawczych odmian współdziałania. Wykorzystuje także identyczną metodę interpretacji znamion sprawczych niewykonawczych odmian współdziałania w odniesieniu do podmiotu odpowiedzialności karnej, przyjmując, że regulacja zawarta w art. 18 § 1 k.k. zdanie trzecie i czwarte ma charakter konstytutywny, wyrażony w przepisie zrębowym, i stanowi podstawę uadekwatnienia poprzez znamiona zaczerpnięte z przepisu określającego postać czynu zabronionego w formie sprawstwa pojedynczego (bezpośredniego) jedynie elementów charakteryzujących znamię czynnościowe oraz ewentualne znamię skutku. Ten model wykładniczy opiera się zatem na wykorzystaniu wprost koncepcji teoretycznej i dogmatycznej, na której opierając się, rekonstruuje się współcześnie podstawy i zakres odpowiedzialności za niesprawcze postaci współdziałania. W tym ujęciu, w części dotyczącej podmiotu odpowiedzialności karnej, przepis art. $18 \S 1$ k.k. zdanie trzecie i czwarte określa samodzielnie znamiona sprawcze niewykonawczych odmian współdziałania, charakteryzując ich podmiot w sposób powszechny ${ }^{68}$. Przepis art. 18 § 1 k.k. zdanie trzecie i czwarte ma w świetle tej koncepcji charakter przepisu zrębowego, uadekwatnianego treściowo przepisami określającymi znamiona typów przestępstw rodzajowych w formie sprawstwa pojedynczego (bezpośredniego). Przy czym uadekwatnienie odnosi się wyłącznie do znamion strony przedmiotowej typów w postaci sprawstwa kierowniczego oraz sprawstwa polecającego, uadekwatnienie nie odnosi się natomiast do charakterystyki podmiotu odpowiedzialności karnej. W konsekwencji sprawstwo kierownicze i sprawstwo polecające mają charakter typów o powszechnym sposobie określenia podmiotu odpowiedzialności karnej. $\mathrm{W}$ tym podejściu przyjmuje się, że kwestia odpowiedzialności za sprawcze odmiany współdziałania w postaci sprawstwa kierowniczego oraz sprawstwa polecającego do przestępstwa indywidualnego została samoistnie uregulowana art. $18 \S 1$ zdanie trzecie i czwarte i nie ma w tym zakresie żadnego znaczenia rozwiązanie przewidziane $\mathrm{w}$ art. 21

czynu zabronionego pod groźbą kary każdy może się dopuścić sprawstwa kierowniczego, sprawstwa polecającego, podżegania oraz pomocnictwa, co oznacza, że nawet ten, kto nie posiada właściwości wskazanych w przepisie określającym znamiona tego czynu zabronionego, może w sposób prawnokarnie relewantny: kierować jego wykonaniem, polecić jego wykonanie, nakłaniać do jego dokonania oraz ułatwiać jego popełnienie" — Ł. Pohl, Wykład..., s. 187.

67 Tak w szczególności ibidem, s. 187 n.

68 Zob. w tej kwestii ibidem, s. 187. Nieco inaczej kwestię tę ujmuje Ł. Pilarczyk, podkreślając, że ,sprawstwo kierownicze będzie miało charakter przestępstwa powszechnego, ponieważ każdy może kierować wykonaniem czynu zabronionego, sprawstwo polecające będzie zaś z kolei przestępstwem indywidualnym, skoro wystąpienie osoby, która jest od nas uzależniona, należy niewątpliwie uznać za cechę indywidualizującą" — idem, Postulaty..., s. 95. 
$\S 2$ k.k. ${ }^{69}$ Natomiast w odniesieniu do sprawstwa pojedynczego (bezpośredniego) oraz współsprawstwa, traktowanych w tym podejściu jako tzw. wykonawcze postaci sprawstwa, zakłada się, iż przepis art. 21 § 2 k.k. nie odgrywa żadnej roli, kompleksowa zaś regulacja podstaw odpowiedzialności karnej zawarta jest w art. $18 \S 1$ k.k. zdanie pierwsze i drugie. Ponieważ w tym zakresie przepis art. 18 $\S 1$ k.k. zdanie drugie nie prowadzi do modyfikacji znamion charakteryzujących podmiot odpowiedzialności karnej w przypadku współsprawczego współdziałania, jest on zatem zawsze określany identycznie jak w przypadku sprawstwa pojedynczego (bezpośredniego), tj. przez przepis typizujący przestępstwo rodzajowe, zawarty w części szczególnej k.k. lub w ustawach pozakodeksowych. Takie podejście przesądza, że podmiot odpowiedzialności karnej w wypadku typu współsprawstwa do przestępstwa indywidualnego, właściwego oraz niewłaściwego, zarówno w postaci kwalifikowanej, jak i uprzywilejowanej, charakteryzowany jest przez znamiona typu w formie sprawstwa pojedynczego (bezpośredniego), a więc jako tzw. podmiot indywidualny. W konsekwencji ze względu na wyłączenie w tym ujęciu zastosowania art. 21 § 2 k.k. do współsprawstwa odpowiedzialności karnej za współsprawstwo przestępstwa indywidualnego podlegać może jedynie współdziałający mający cechy wymagane od sprawcy przestępstwa indywidualnego (a więc jedynie intraneus). W razie braku tych cech przyjmuje się, iż współdziałający ekstraneus ponosić powinien odpowiedzialność za pomocnictwo $^{70}$. W tej koncepcji nie wyjaśniono charakteru przepisu art. $18 \S 1$ k.k. zdanie pierwsze i drugie, w szczególności zaś tego, czy ma on w odniesieniu do sprawstwa pojedynczego (bezpośredniego) oraz współsprawstwa status przepisu zrębowego, uadekwatnianego przez określające znamiona przestępstwa rodzajowego przepisy części szczególnej lub przepisy pozakodeksowe, czy też art. 18 § 1 k.k. zdanie pierwsze i drugie ma status przepisu uadekwatniającego w stosunku do uznawanych w tym przypadku za zrębowe przepisów określających znamion przestępstw rodzajowych zawartych w części szczególnej lub ustawach pozakodeksowych. Nie wyjaśniono także, czy w związku z odmiennością co do rekonstrukcji znamion typów określających postaci sprawstwa kierowniczego i polecającego oraz sprawstwa pojedynczego (bezpośredniego) i współsprawstwa przepis art. 18 $\S 1$ k.k. ma dwoistą naturę normatywną, czy też jest przepisem jednorodnym. Nie wyjaśniono także funkcji pełnionych przez art. $18 \S 1$ k.k. w odniesieniu do sprawstwa pojedynczego (bezpośredniego), współsprawstwa, sprawstwa kierowniczego oraz sprawstwa polecającego. Warto zaznaczyć, że o ile w wypadku sprawstwa pojedynczego (bezpośredniego), ze względu na zawarcie pełnej charakterystyki typu czynu zabronionego w przepisach zamieszczonych w części szczególnej lub

69 Tak m.in. Ł. Pilarczyk, podkreślając, że ,artykuł $21 \S 2$ k.k. nie powinien mieć zatem w ogóle zastosowania do sprawstw kierowniczego ani polecającego, a określenie »współdziałający « zawarte w tym przepisie nie powinno się do nich w ogóle odnosić" —idem, Postulaty..., s. 97.

${ }^{70}$ Ł. Pohl, Wyktad..., s. 187 n. 
przepisach pozakodeksowych, nie ma większych trudności, by stwierdzić, że to właśnie te przepisy mają charakter zrębowy, o tyle w odniesieniu do współsprawstwa sprawa nie jest już tak oczywista, albowiem przepis art. $18 \S 1$ k.k. zdanie drugie określa charakterystyczne elementy znamion strony przedmiotowej i strony podmiotowej typu współsprawstwa, co sprawia, iż z teoretycznego punktu widzenia możliwe jest określanie jego statusu i funkcji jako przepisu zrębowego albo jako przepisu uadekwatniającego. Wybór jednej z rysujących się możliwości związany jest z rozstrzygnięciem wielu kwestii, w tym m.in. akceptacji lub odrzucenia zasady równorzędności sprawstwa oraz wszystkich sprawczych postaci współdziałania i przyjęcia albo odrzucenia zasady akcesoryjności lub nieakcesoryjności sprawczych postaci współdziałania. Zarazem trudno znaleźć dostateczne podstawy do różnicowania statusu, charakteru i funkcji art. $18 \S 1 \mathrm{k} . \mathrm{k}$. w odniesieniu do sprawstwa pojedynczego i współsprawstwa $\mathrm{z}$ jednej strony oraz sprawstwa kierowniczego i sprawstwa polecającego — z drugiej. Trudno w tym kontekście pozbyć się wrażenia, że stanowisko różnicujące, oparte na statusie, charakterze i znaczeniu art. 18 § 1 k.k., a w konsekwencji odmiennie traktujące współsprawstwo oraz sprawstwa kierownicze i sprawstwo polecające, narażone jest na zarzut wewnętrznej niespójności.

W piśmiennictwie prezentowany jest także pogląd, zgodnie z którym wszystkie odmiany sprawczego współdziałania uregulowane zostały z wykorzystaniem modelu prowadzącego do modyfikacji charakterystyki podmiotu odpowiedzialności karnej przez treść art. $18 \S 1$ k.k. zdanie drugie, trzecie i czwarte, określającej podmiot współsprawstwa, sprawstwa kierowniczego i sprawstwa polecającego jako tzw. podmiot powszechny. W konsekwencji wszystkie sprawcze odmiany współdziałania — zarówno do przestępstwa powszechnego, jak i wszystkich odmian przestępstw indywidualnych — określone zostały przez ustawodawcę jako typy powszechne (ogólnsprawcze) ${ }^{71}$. Odpowiedzialność ekstraneusa za współsprawstwo, sprawstwo kierownicze i sprawstwo polecające do przestępstwa indywidualnego jest zatem możliwa ze względu na charakterystykę typu współsprawstwa, sprawstwa kierowniczego oraz sprawstwa polecającego ${ }^{72}$. Ewentualne ograniczenia odpowiedzialności ekstraneusa za sprawcze współdziałanie w po-

71 W odniesieniu do współsprawstwa w tym ujęciu podkreśla się, że „nie ma żadnych przeciwwskazań do tego, aby traktować współsprawstwo tak samo jak sprawstwo kierownicze i sprawstwo polecające - czyli tak jak odrębny czyn zabroniony. Jego podmiotem mógłby zostać każdy, bądź też jedynie osoby posiadające szczególne cechy, jak przy niektórych przestępstwach indywidualnych, [...], takich jak dezercja. Niektóre przestępstwa współsprawstwa będą więc miały charakter indywidualnych, kiedy indziej zaś powszechnych, w zależności od tego, do jakiego czynu zabronionego z części szczególnej k.k. się odnoszą. Wynika z tego, że dopuszczalna jest konstrukcja powszechnego przestępstwa współsprawstwa w popełnieniu przestępstwa indywidualnego" Ł. Pilarczyk, Postulaty..., s. 109.

72 Trzeba zaznaczyć, że to stanowisko jest z pewnością wewnętrznie spójne, inną kwestią jest natomiast odpowiedź na pytanie, czy jest merytorycznie trafne. 
pełnieniu przestępstwa indywidualnego wynikać mogą jedynie z charakterystyki poszczególnych odmian przestępstw indywidualnych ${ }^{73}$. W tym ujęciu wskazuje się na zbędność regulacji zawartej w art. 21 § 2 k.k. w zakresie określania podstaw odpowiedzialności karnej za sprawcze i niesprawcze postaci współdziałania w popełnieniu przestępstwa indywidualnego ${ }^{74}$.

Spoglądając z perspektywy przedstawionych uwag, łatwo dostrzec, że w zakresie podstaw odpowiedzialności za sprawcze współdziałanie w popełnieniu przestępstwa indywidualnego $\mathrm{w}$ polskim piśmiennictwie prezentowane są trzy różniące się ujęcia, z których jedno opiera się na stanowisku, wedle którego przepisy określające podstawy odpowiedzialności za sprawcze postaci współdziałania nie modyfikują charakterystyki podmiotu odpowiedzialności karnej, zawartej w przepisie określającym znamiona formy sprawstwa pojedynczego (bezpośredniego). Dwie pozostałe opierają się zasadniczo na modelu, zgodnie z którym przepis art. $18 \S 1$ k.k., określając podstawy odpowiedzialności za sprawcze postaci współdziałania, samoistnie charakteryzuje podmiot odpowiedzialności karnej w sposób powszechny, co sprawia, iż to właśnie ten przepis rozstrzyga zagadnienie odpowiedzialności za sprawcze postaci współdziałania do przestępstwa indywidualnego. Zarazem w ramach tego ujęcia wyróżnić można stanowisko radykalne, przyjmujące, że przepis art. $18 \S 1$ k.k. określa samoistnie jako powszechny podmiot odpowiedzialności karnej w odniesieniu do każdej postaci sprawczego współdziałania, oraz ujęcie umiarkowane, przyjmujące, że przepis art. 18 § 1 k.k. określa samoistnie podmiot odpowiedzialności karnej jedynie w odniesieniu do tzw. niewykonawczych odmian sprawczego współdziałania, tj. sprawstwa kierowniczego i sprawstwa polecającego, i w tym zakresie reguluje kwestie odpowiedzialności za te odmiany współdziałania w popełnieniu przestępstwa indywidualnego w pełnym zakresie. Natomiast w odniesieniu do tzw. wykonawczej odmiany sprawczego współdziałania, tj. współsprawstwa, przyjmuje, że przepis art. $18 \S 1$ k.k. zdanie drugie nie określa samoistnie podmiotu odpowiedzialności karnej,

${ }^{73} \mathrm{~W}$ tym zakresie wskazuje się, że niektóre typy przestępstw indywidualnych (zasadniczo właściwych, choć nie wyłącznie) zostały skonstruowane w taki sposób, że czynność wykonawcza powiązana jest nierozerwalnie $\mathrm{z}$ cechami podmiotu danego przestępstwa, wręcz wynika $\mathrm{z}$ tych cech. W tych przypadkach, określanych mianem przestępstw indywidualnych co do czynu. W konsekwencji wskazuje się, że „współsprawstwo ekstraneusa z intraneusem będzie więc zazwyczaj możliwe przy tych przestępstwach indywidualnych określanych jako indywidualne co do podmiotu, a więc tych, w których szczególna okoliczność nie dotyczy znamienia czasownikowego, ale jedynie podmiotu czynu zabronionego - matki, żołnierza. Nie będzie więc możliwe np. nie będąc spokrewnionym z jakąś osobą, dokonać z nią kazirodztwa, podobnie jak cywil nie może dokonać dezercji wraz z żołnierzem. Niektóre przestępstwa współsprawstwa będą więc rzeczywiście mieć charakter indywidualnych" — Ł. Pilarczyk, Postulaty..., s. 108-109.

74 Jednoznaczne jest w tej kwestii stanowisko Ł. Pilarczyka, podkreślającego, że ,przepis ten jest regulacją całkowicie zbędną w obecnym systemie prawa karnego, a jego obecność jedynie zaciemnia zasady ponoszenia odpowiedzialności karnej za przestępne współdziałanie" — idem, Postulaty..., s. 110. Na zbędność art. 21 § 2 k.k. wskazuje także Ł. Pohl, Wykład..., s. 187 n. 
kwestie te regulują przepisy określające formę sprawstwa pojedynczego (bezpośredniego), ze względu zaś na charakter tej postaci sprawstwa odpowiedzialność karna za współdziałanie w popełnieniu przestępstwa indywidualnego możliwa jest jedynie wówczas, gdy współsprawczo współdziałający ma cechy wymagane od sprawcy przestępstwa indywidualnego. W obu odmianach analizowane w tym miejscu ujęcie całkowicie odrzuca możliwość uznania, że kwestie odpowiedzialności za sprawcze postaci współdziałania reguluje art. $21 \S 2$ k.k. oparty na modelu wskazania przesłanek prowadzących do przyjęcia fikcji spełnienia przez ekstraneusa warunków wymaganych od podmiotu odpowiedzialności karnej w przypadku przestępstwa indywidualnego.

W konsekwencji można stwierdzić, że w polskim piśmiennictwie prezentowane są koncepcje objaśniające podstawy i zakres odpowiedzialności za współdziałanie w popełnieniu przestępstwa indywidualnego, wykorzystujące oba wskazane modele, tj. zarówno model prowadzący do przekształcenia w wypadkach współdziałania w popełnieniu przestępstwa o indywidualnej charakterystyce podmiotu sprawczego przewidzianej dla formy sprawstwa pojedynczego (bezpośredniego) w przestępstwo powszechne w odniesieniu do typów charakteryzujących poszczególne postaci współdziałania, jak i model oparty na regulacji szczególnej, wskazującej na możliwość przyjęcia fikcji spełniania przez ekstraneusa warunków wymaganych od sprawcy przestępstwa indywidualnego w razie niektórych odmian przestępnego współdziałania. Przedstawiane są także koncepcje nawiązujące do ujęcia opartego na jednoczesnym wykorzystaniu modelu prowadzącego do przekształcenia w wypadkach współdziałania przestępstwa o indywidualnej charakterystyce podmiotu sprawczego, przewidzianej dla formy sprawstwa pojedynczego (bezpośredniego), w przestępstwa o powszechnej charakterystyce podmiotu w przypadków typów charakteryzujących poszczególne postaci współdziałania oraz modelu opartego na regulacji szczególnej, wskazującej na możliwość przyjęcia fikcji spełniania przez ekstraneusa warunków wymaganych od sprawcy przestępstwa indywidualnego w razie niektórych odmian przestępnego współdziałania.

Zasadnicze rozbieżności dotyczą zagadnienia podstaw odpowiedzialności za sprawcze postaci współdziałania w popełnieniu przestępstwa indywidualnego. Mają one nadto charakter konstrukcyjny, związany z najgłębszymi podstawami odpowiedzialności za sprawstwo we wszystkich odmianach. Zasadniczo wynikają z nieprecyzyjnej, dalekiej od doskonałości ustawowej regulacji podstaw odpowiedzialności za sprawcze postaci współdziałania, zawartej w art. 18 § 1 k.k. zdanie drugie, trzecie i czwarte, wynikającej — jak się wydaje — z braku dostatecznie klarownej koncepcji teoretycznej dotyczącej istoty sprawstwa w polskim systemie prawa karnego oraz kryminalnopolitycznych założeń związanych z podstawami i zakresem odpowiedzialności za sprawstwo. Dodatkowym źródłem komplikacji i rozbieżności stanowisk jest historycznie nieprzemyślany i za- 
skakujący proces stopniowego zwiększania zakresu sprawczych postaci współdziałania kosztem zmniejszania zakresu odpowiedzialności karnej za niesprawcze postaci współdziałania, notabene całkowicie niezrozumiały w systemie opartym na założeniu równorzędności wszystkich form popełnienia przestępstwa, umożliwiających wymierzenie współdziałającemu w dowolnej postaci (sprawczej lub niesprawczej) takich samych konsekwencji, jakie ustawa przewiduje dla sprawcy pojedynczego (bezpośredniego ${ }^{75}$. Ten zabieg, początkowo objawiający się wprowadzeniem do kodeksu karnego z 1969 r. konstrukcji sprawstwa kierowniczego, następnie zaś — w kodeksie karnym z 1997 r. — dodatkowo konstrukcji sprawstwa polecającego ${ }^{76}$, bez jednoczesnego klarownego przemyślenia i przedstawienia powodów takiej decyzji oraz wynikających z niej warunków odpowiedzialności za sprawstwo, w tym także za sprawcze postaci współdziałania, połączony dodatkowo z niefortunnym ujęciem sprawczych postaci współdziałania w kontekście akcesoryjności lub samodzielności odpowiedzialności w tym zakresie, powoduje, że obowiązujące regulacje z uwagi na niejednoznaczność oraz błędy konstrukcyjne i technicznolegislacyjne umożliwiają prezentowanie różnorodnych koncepcji wyjaśniających istotę sprawstwa i sprawczych postaci współdziałania w polskim systemie prawa, a także niejako w konsekwencji różnorodnych modeli objaśniania podstaw i zakresu odpowiedzialności za sprawcze współdziałanie w popełnieniu przestępstwa indywidualnego. Spory dotyczące znaczenia regulacji przewidzianej w art. $21 \S 2$ k.k. w zakresie odpowiedzialności za niesprawcze współdziałanie w popełnieniu przestępstwa indywidualnego niewłaściwego typu uprzywilejowanego, jakkolwiek zasadzają się na odmiennych założeniach kryminalnopolitycznych, zasadniczo tkwią w nieklarowności podstaw odpowiedzialności za sprawstwo i sprawcze postaci współdziałania oraz wynikającej stąd potrzebie wprowadzenia do kodeksu karnego szczególnego przepisu regulującego to zagadnienie. Samoistnym źródłem problemów jest nad wyraz nieklarowny, wadliwy z technicznolegislacyjnego punktu widzenia oraz nieoparty na klarownej koncepcji teoretycznej przepis art. $21 \S 2$ k.k., który — chyba dość bezrefleksyjnie — wprowadzono jako swoistą kalkę regulacji zawartej w art. 19 § 2 k.k. z 1969 r.,

75 Zwiększanie zakresu sprawczych postaci współdziałania wyjaśniać można m.in. intuicyjną i zarazem w znacznym stopniu zabarwioną populistycznie potrzebą „usprawczania” coraz to nowych postaci współdziałania, związaną z opartymi na powszechnych intuicjach sprawiedliwościowych przekonaniach, że sprawstwo w dowolnej postaci to coś „więcej” niż podżeganie i pomocnictwo. Nie sposób przedstawić w jednym przypisie wykazu szkód, jakie dla polskiego systemu prawa karnego wyniknęły w ciągu lat z tego sposobu rozumowania, stanowiącego podstawę do kolejnych ingerencji w zakres regulacji sprawczych i niesprawczych postaci współdziałania. Zob. w tej kwestii m.in. M. Bielski, Sprawstwo zleceniodawcze w projekcie nowelizacji kodeksu karnego, „Prokuratura i Prawo” 2006, nr 10, s. 46-68.

$76 \mathrm{~W}$ późniejszym okresie postulowano wprowadzenie piątej odmiany sprawstwa, a czwartej postaci - sprawczego współdziałania w postaci tzw. sprawstwa zleceniodawczego. Zob. szerzej w tej kwestii ibidem. 
zapominając zarazem, że zwiększenie zakresu tej — szczególnej w założeniu twórców — regulacji na sprawcze formy współdziałania wymaga głębokiego przemyślenia oraz nad wyraz starannej redakcji ${ }^{77}$. Istotnym czynnikiem komplikującym teoretycznie objaśnienie i dogmatyczny opis podstaw odpowiedzialności za współdziałanie w popełnieniu przestępstwa indywidualnego jest to, że polski ustawodawca nigdy głębiej nie rozważył i w konsekwencji nie rozstrzygnął, na jakim modelu zamierza oprzeć regulację dotyczącą tej sfery odpowiedzialności karnej, tj. czy decyduje się na wykorzystanie modelu prowadzącego do przekształcenia podmiotu odpowiedzialności karnej w przypadkach przestępnego współdziałania do przestępstw indywidualnych w podmiot o charakterystyce powszechnej, czy też zagadnienie to zamierza rozwiązywać poprzez model regulacji szczególnej, zachowujący indywidualny charakter typów w formie przestępnego współdziałania do przestępstwa indywidualnego, z możliwością przyjęcia fikcji spełnienia przez ekstraneusa warunków wymaganych od sprawcy przestępstwa indywidualnego w formie sprawstwa pojedynczego (bezpośredniego) w razie spełnienia określonych w ustawie warunków ${ }^{78}$. Spojrzenie na ustawową regulację w tym zakresie zdaje się wskazywać, że wykorzystano model prowadzący do modyfikacji charakterystyki podmiotu odpowiedzialności karnej w przypadku niesprawczego współdziałania, z wyją̧tkiem opartym na modelu alternatywnym w zakresie odpowiedzialności za niesprawcze postaci współdziałania w popełnieniu przestępstwa

77 Na wadliwości konstrukcyjne oraz niedoskonałości technicznolegislacyjne art. $21 \S 2$ k.k. wskazują w zasadzie wszyscy komentatorzy. Zaskakujące, ale problemy związane z interpretacją tego przepisu sygnalizowane były już w pierwszych komentarzach przez współtwórców tej regulacji, dokonujących ad hoc wykładni i poszukujących racjonalizacji zawartych w nim sformułowań. Zob. w tej kwestii A. Zoll [w:] K. Buchała, A. Zoll, op. cit., s. 176.

78 Warto podkreślić, że określenie teoretycznych podstaw odpowiedzialności za niesprawcze postaci współdziałania w popełnieniu przestępstwa indywidualnego, powszechnie w zasadzie niekwestionowane w polskiej doktrynie, dokonało się w pewnym sensie przypadkiem, w związku z przeprowadzonym na początku XXI w. procesem teoretycznej rekonstrukcji modelu odpowiedzialności za podżeganie i pomocnictwo, wypracowanym przez J. Makarewicza zasadniczo w oparciu o ustawową treść k.k. z 1932 r., traktowane powszechnie jak wyraz wypracowanej przez tego autora koncepcji teoretycznej. Trzeba jednak pamiętać, że model teoretyczny był w tym przypadku odtwarzany (rekonstruowany) na podstawie ustawowej regulacji stworzonej zasadniczo przez J. Makarewicza, przy ewidentnym braku wypowiedzi o teoretycznym charakterze, które poprzedzałyby przeniesienie tego modelu na konkretne zapisy ustawowe. Nie można także tracić z pola widzenia, że przedstawiona w pierwszej dekadzie XXI w. rekonstrukcja koncepcji teoretycznej J. Makarewicza w kilku obszarach prowadzi do konsekwencji, które autor koncepcji uważał już w latach 30. ubiegłego stulecia za oczywiście nietrafne i pozostające w sprzeczności z opracowanym przez niego modelem tzw. polskiej konstrukcji podżegania i pomocnictwa. Rozbieżność rekonstrukcyjna dotyczy w szczególności zakresu i podstaw odpowiedzialności za podżeganie i pomocnictwo do przestępstwa indywidualnego. W odniesieniu do sprawstwa i sprawczych postaci współdziałania, mimo opublikowania wielu prac, nie udało się wypracować spójnego i zarazem kompleksowego ujęcia teoretycznego. Brak również analiz dotyczących modelowych koncepcji rozstrzygania określonych problemów w kodeksie karnym. 
indywidualnego niewłaściwego typu uprzywilejowanego, oraz model regulacji szczególnej zachowującej indywidualną charakterystykę podmiotu odpowiedzialności karnej w przypadku sprawczego współdziałania w popełnieniu przestępstwa indywidualnego z regulacją szczególną, określającą warunki, których spełnienie umożliwia przyjęcie fikcji prawnej spełnienia przez ekstraneusa warunków wymaganych od sprawcy przestępstwa indywidualnego.

W odniesieniu do sprawczych postaci współdziałania ekstraneusa w popełnieniu przestępstwa indywidualnego można stwierdzić, że zasadnicza część aktualnie analizowanych w piśmiennictwie karnistycznym zagadnień związana jest z niezbyt fortunnymi zmianami normatywnymi, wprowadzonymi w zakresie odpowiedzialności karnej za sprawcze postaci współdziałania. Spoglądając z perspektywy historycznej, można dostrzec, że po wejściu w życie kodeksu karnego z 1997 r. podstawowym źródłem kontrowersji była kwestia możliwości pociągania do odpowiedzialności karnej ekstraneusa za niesprawcze postaci współdziałania $\mathrm{w}$ popełnieniu przestępstwa indywidualnego. W żadnym zakresie, $\mathrm{z}$ różnych zresztą powodów, w okresie międzywojennym nie rozważano zagadnienia odpowiedzialności karnej ekstraneusa za sprawcze postaci współdziałania w popełnieniu przestępstwa indywidualnego. Trzeba zarazem wskazać, że problem podżegania i pomocnictwa ekstraneusa do przestępstwa indywidualnego był w okresie międzywojennym rozwiązywany w sposób konsekwentny, choć na dwa wzajemnie przeciwstawne sposoby. Twórca polskiej koncepcji podżegania i pomocnictwa — J. Makarewicz — przyjmując założenie, że przestępstwo indywidualne może popełnić jedynie intraneus $\mathrm{w}$ formie sprawstwa pojedynczego (bezpośredniego), całkowicie wykluczał możliwość konstruowania podstaw odpowiedzialności karnej za podżeganie i pomocnictwo do przestępstwa indywidualnego — zarówno w odniesieniu do podżegacza i pomocnika mającego status intraneusa w perspektywie charakterystyki podmiotu odpowiedzialności karnej, zawartej w typie określającym znamiona sprawstwa pojedynczego (bezpośredniego), jak i w odniesieniu do podżegacza i pomocnika mających z tego punktu widzenia status ekstraneusa. Z kolei stanowisko przeciwne opierało się na założeniu, że odpowiedzialność za współdziałanie w popełnieniu przestępstwa indywidualnego nie jest — wbrew twierdzeniu J. Makarewicza - wykluczona oraz przyjmowało, że możliwe jest pociągnięcie do odpowiedzialności karnej ekstraneusa za podżeganie i pomocnictwo do przestępstwa indywidualnego przy spełnieniu określonych warunków. Jakkolwiek przedstawione tu koncepcje były skrajnie przeciwstawne, to jednak nie sposób odmówić im wewnętrznej spójności. W perspektywie przeprowadzonych wiele lat później analiz można konstatować, że trafnie kwestię odpowiedzialności karnej ekstraneusa za podżeganie i pomocnictwo do przestępstwa indywidualnego ujmowali przeciwnicy J. Makarewicza, wskazując, że jest ona z oczywistych powodów konstrukcyjnie możliwa, wynika z istoty konstrukcji podżegania i pomocnictwa na gruncie polskiego systemu prawa karnego i wymaga skierowania czyn- 
ności nakłaniania lub ułatwiania na osobę bezpośredniego wykonawcy, mającego status intraneusa, oraz oczywistej z perspektywy znamion strony podmiotowej typów podżegania i pomocnictwa świadomości nakłaniającego lub ułatwiającego ekstraneusa, że kierują swoje czynności do osoby bezpośredniego wykonawcy, mającej cechy wymagane od sprawy przestępstwa o zawężonym kręgu podmiotów sprawczych. Rozstrzygnięcie w sposób prawidłowy kwestii podstaw odpowiedzialności ekstraneusa za podżeganie i pomocnictwo do przestępstwa indywidualnego opierało się zatem na prawidłowej wykładni przepisów określających podstawy odpowiedzialności za podżeganie i pomocnictwo, i nie wymagało wprowadzania do kodeksu karnego żadnej szczególnej regulacji w tym zakresie.

Niedostrzeżenie teoretycznych podstaw rozwiązania problemu odpowiedzialności ekstraneusa za podżeganie i pomocnictwo do przestępstwa indywidualnego, wypracowanego w okresie międzywojennym, oraz — jak można przypuszczać — brak dostatecznej refleksji teoretycznej i dogmatycznej nad tym zagadnieniem skutkował nieprzemyślaną i wielce kłopotliwą decyzją o wprowadzeniu do kodeksu karnego z 1969 r. regulacji szczególnej, dotyczącej podstaw odpowiedzialności ekstraneusa za podżeganie i pomocnictwo do przestępstwa indywidualnego. Rozwiązanie to, niewnoszące niczego z punktu widzenia podstaw odpowiedzialności za podżeganie i pomocnictwo do przestępstwa indywidualnego, połączone z wprowadzeniem do art. 16 k.k. z 1969 r. konstrukcji sprawstwa kierowniczego oraz ustawowego uregulowania współsprawstwa w sposób umożliwiający jego nad wyraz szeroką interpretację, stworzyły podstawy do rozważania kwestii ewentualnych podstaw odpowiedzialności karnej ekstraneusa za współsprawstwo oraz sprawstwo kierownicze przestępstwa indywidualnego. Można w tym kontekście twierdzić, że w pewnym zakresie niefortunne i niedostatecznie przemyślane ustawowe uregulowanie kwestii podstaw odpowiedzialności karnej ekstraneusa za podżeganie i pomocnictwo do przestępstwa indywidualnego, notabene całkowicie zbędne, wygenerowało trudności i wątpliwości związane z odpowiedzialnością ekstraneusa za sprawcze postaci współdziałania w popełnieniu przestępstwa indywidualnego. Komplikacje w tym zakresie związane były tyleż z regulacją zawartą w art. 19 § 2 k.k. z 1969 r., co brakiem klarownej koncepcji teoretycznej uregulowania podstaw odpowiedzialności karnej za sprawstwo oraz sprawcze postaci współdziałania. Podczas obowiązywania kodeksu karnego z 1969 r. nie przedstawiono jednak spójnej teoretycznej koncepcji w tym zakresie, nie rozważono także wszystkich kwestii związanych z problemem ewentualnej odpowiedzialności ekstraneusa za sprawcze postaci współdziałania w popełnieniu przestępstwa indywidualnego, lecz zdecydowano się na pozbawiony podstaw teoretycznych zabieg, polegający na „automatycznym” zwiększeniu zakresu szczególnej regulacji dotyczącej, w zamyśle twórców, podstaw odpowiedzialności ekstraneusa za podżeganie i pomocnictwo do przestępstwa indywidualnego na sprawcze postaci współdziałania, połączony z dodaniem kolejnej formy sprawczego współdziałania 
w postaci tzw. sprawstwa polecającego. Zarazem regulacja dotycząca sprawczych postaci współdziałania w kodeksie karnym z 1997 r. pozbawiona była teoretycznej analizy i ujęta w sposób wadliwy technicznolegislacyjnie. W ten sposób, usiłując rozwiązać problem odpowiedzialności karnej ekstraneusa za sprawcze postaci współdziałania w popełnieniu przestępstwa indywidualnego, stworzono regulację, która samoistnie generuje wiele problemów. Ostatecznie aktualnie nie ma w zasadzie wątpliwości odnośnie do sposobu rozstrzygania podstaw odpowiedzialności ekstraneusa za podżeganie i pomocnictwo do przestępstwa indywidualnego, co było poważnym problemem w okresie międzywojennym, istnieją zaś fundamentalne wręcz wątpliwości związane z konstrukcjami wprowadzonymi do kodeksu karnego z 1997 r. w celu rzekomego rozwiązania dawnych problemów. Wypracowane w polskim piśmiennictwie koncepcje teoretyczne dotyczące sprawstwa, sprawczych oraz niesprawczych postaci współdziałania stwarzają dobrą podstawę do uporządkowania ustawowej regulacji dotyczącej współdziałania, w tym także w obszarze dotyczącym przestępstw indywidualnych, wymagają jednak przedstawienia klarownej koncepcji kryminalnopolitycznej, albowiem wybór rozwiązania kryminalnopolitycznego decydować będzie o wykorzystaniu jednego z opisanych teoretycznych modeli. Warto wyrazić nadzieję, że ewentualne zmiany normatywne w tym zakresie poprzedzone zostaną — inaczej niż w przeszłości — właściwymi analizami oraz przyjęciem klarownych założeń kryminalnopolitycznych, co stanowi jeden z podstawowych warunków uniknięcia błędów popełnionych przy opracowywaniu projektów kodeksu karnego z 1969 r. oraz kodeksu karnego z $1997 \mathrm{r}$.

Podsumowując, można stwierdzić, że zasadniczym zadaniem polskiej dogmatyki i teorii prawa karnego jest wypracowanie spójnej koncepcji odpowiedzialności za współdziałanie w popełnieniu przestępstwa indywidualnego, uwzględniającej wiele okoliczności związanych z płaszczyzną politycznokryminalną ${ }^{79}$, a następnie przedstawienie koncepcji ustawowego uregulowania tej kwestii przy wykorzystaniu jednego z modeli lub różnych modeli w zależności od postaci współdziałania, ostatecznie zaś opracowanie poprawnych technicznolegislacyjnie i odpowiadających wybranemu modelowi teoretycznemu przepisów odnoszących się do tej prob-

79 Zob. sugestywny przykład J. Giezka, dotyczący matki nakłaniającej lekarza w okresie porodu i pod wpływem jego przebiegu do zabicia jej rodzącego się właśnie dziecka, co prowadzić powinno, zdaniem tego autora, do odpowiedzialności za podżeganie do popełnienia przestępstwa podżegania do przestępstwa indywidualnego niewłaściwego typu uprzywilejowanego, co z kolei na gruncie przyjmowanych przez polskiego ustawodawcę rozwiązań wydaje się mocno utrudnione, o ile w ogóle możliwe — zob. J. Giezek [w:] J. Giezek, N. Kłączyńska, G. Łabuda, op. cit., s. 185186. Przykład ten dobrze ilustruje znaczenie aspektów aksjologicznych i kryminalnopolitycznych przy rozstrzyganiu kwestii teoretycznego i modelowego rozwiązania zagadnienia odpowiedzialności za współdziałanie w popełnieniu przestępstwa indywidualnego. Może również stanowić intrygującą podstawę do kwestionowania poprawności modelu odpowiedzialności za podżeganie i pomocnictwo, opartego na współczesnej rekonstrukcji koncepcji J. Makarewicza. 
lematyki. Bez wykonania tego zadania nie sposób uniknąć rozbieżności poglądów oraz różnorodności koncepcji objaśniających obowiązujące przepisy.

Niezależnie od przedstawionych uwag problem podstaw odpowiedzialności za współdziałanie w popełnieniu przestępstwa indywidualnego rozwiązywać można sensownie jedynie przy uwzględnieniu specyfiki i różnorodności przestępstw indywidualnych, rzutujących w wielu wypadkach na kwestie odpowiedzialności ekstraneusa za współdziałanie w popełnieniu takiego przestępstwa. Zasadnie wskazuje się w piśmiennictwie, że w niektórych przypadkach przestępstw indywidualnych, ze względu na ich charakterystykę oraz właściwości konstrukcyjne, niezwykle utrudnione, o ile w ogóle możliwe, jest konstruowanie podstaw odpowiedzialności ekstraneusa ${ }^{80}$. Tym samym niezależnie od wskazanych zagadnień związanych z teoretycznymi i dogmatycznymi, a także modelowymi podstawami regulacji dotyczącej współdziałania w popełnieniu przestępstwa indywidualnego zasadne wydaje się przedstawienie spójnej koncepcji przestępstw indywidualnych, obejmującej ich normatywną charakterystykę, cechy konstrukcyjne, podstawy tworzenia, możliwe kategoryzacje, wreszcie - powiązanie poszczególnych odmian przestępstw indywidualnych z właściwościami sprawcy przestępstw o zawężonym kręgu podmiotów. Tak ukształtowane ustalenia stanowić mogą podstawę rozstrzygnięcia pytania o możliwość realizacji w formie współdziałania - sprawczego i niesprawczego — poszczególnych typów przestępstw indywidualnych, a w konsekwencji wyznaczenia obszaru, do którego odnosić się mogą, w razie potwierdzenia kryminalnopolitycznego, teoretycznego i modelowego uzasadniania, konstrukcje współdziałania ${ }^{81}$.

\section{A few thoughts on how to resolve disputes concerning agential cooperation in individual crimes}

Summary

The following research paper is devoted to the analysis of the issue of criminal liability of the extraneus for agential cooperation in committing an individual crime. It sets out to describe the historical concept of the extraneus' responsibility for his cooperation in committing an individual crime and to further evaluate the fundamental theoretical, criminal, political and dogmatic problems associated with the above mentioned matter.

80 Zob. w tym zakresie niezwykle interesujące rozważania R. Dębskiego, Współdziałanie..., s. 13 n.; J. Giezka [w:] J. Giezek, N. Kłączyńska, G. Łabuda, op. cit., s. 185-186; Ł. Pilarczyka, Postulaty..., s. 108-109; idem, Istota..., s. 189 n.

81 Inną zupełnie kwestią związaną z poruszanymi zagadnieniami jest problem możliwości zrealizowania w formie sprawczego lub niesprawczego współdziałania znamion poszczególnych odmian przestępstw indywidualnych w świetle aktualnie obowiązujących w tym zakresie przepisów. Analizy stanowić mogą interesujące i zarazem przydatne uzupełnienie zamieszczonych rozważań dotyczących konstrukcyjnych aspektów współdziałania w popełnieniu przestępstwa indywidualnego, analizowanych z perspektywy poszczególnych postaci współdziałania. 
When it comes both to the criminal and political aspects, our analysis focuses on how to justify grounds for criminal liability in cases where the perpetrator of an individual cooperative crime does not fulfill the statutory requirements which must be met so as to constitute such an offense.

As for the theoretical aspect, it depicts the possible models of solving the extraneous' liability issue by juxtaposing two mutually exclusive conceptions. First of these is based on the modification of the elements of an individual offense, thus transforming it into a crime that can be perpetrated by any offender (ordinary crime?) in case of agential cooperation. The second one, however, advocates including new elements into the criminal code, the actualization of which will constitute grounds for accepting the extraneus' liability for cooperation in committing an individual crime without modifying the statutory characteristics of the agential subject.

Finally, the dogmatic insights review the current regulations and provisions.

To sum up, it is proposed to order the statutory regulations by using and implementing one of the aforementioned theories.

Keywords: criminal law, individual crime, co-operation in committing the crime, criminal responsibility. 